ISSN 1980 - 6477

Journal homepage: www.abms.org.br/site/paginas

Camilo de Lelis Teixeira de Andrade ${ }^{(1)}(\bowtie)$, Bruna Gomes Magalhães ${ }^{(1)}$, Daniela de Carvalho Lopes ${ }^{(2)}$ Antonio José Steidle Neto(2), Isabel Regina Prazeres de Souza ${ }^{(1)}$ and Tales Antônio Amaral ${ }^{(1)}$

(1) Embrapa Milho e Sorgo

Email: camilo.andrade@embrapa.br

edu.brunamagalhaes@gmail.com

tales_aamaral@yahoo.com.br

isabel.prazeres@embrapa.br

(2) Universidade Federal de São João del Rei

Email: danielalopes@ufsj.edu.br

antonio@ufsj.edu.br

Corresponding author

How to cite

ANDRADE, C. L. T.; MAGAlHÃES, B. G. LOPES, D. C.; STEIDLE NETO, A. J.; SOUZA, I. R. P.; AMARAL, T. A. Modelling managemen strategies to mitigate the effects of alterations of temperature and of $\mathrm{CO}_{2}$ concentration on maize Revista Brasileira de Milho e Sorgo, v. 20, e1210 2021.

\section{MODELLING MANAGEMENT STRATEGIES TO MITIGATE THE EFFECTS OF ALTERATIONS OF TEMPERATURE AND OF $\mathrm{CO}_{2}$ CONCENTRATION ON MAIZE}

Abstract - Ongoing climate change may affect rainfed maize yield in Brazil, which can be attenuated by some crop management strategies. This work aimed to evaluate, by using computational modeling, management practices with potential to mitigate the effects of changes in temperature and $\mathrm{CO}_{2}$ concentration on maize yield. The CSM-CERES-Maize model was applied to simulate the mitigating potential of using maize cultivars with $0.3 \mathrm{~m}, 0.5 \mathrm{~m}$ and $0.7 \mathrm{~m}$ deep root system, associated with $0 \mathrm{tha}^{-1}, 2 \mathrm{tha}^{-1}$ and $4 \mathrm{tha}^{-1}$ of crop residue left on the soil surface. A set of 33 years of daily weather data, along with soil profile data, were used to evaluate the approach in 10 regions of the state of Minas Gerais, Brazil. For most of the regions, the use of mulching and of a maize cultivar with deeper root system was not capable of attenuating the temperature rise. In contrast, any factor limiting root growth of maize to a depth of $0.30 \mathrm{~m}$, causes significant yield drop, even for a scenario of reducing temperature by $3{ }^{\circ} \mathrm{C}$ or rising $\mathrm{CO}_{2}$ concentration. In warmer and drier regions, the positive response of maize to the increase in $\mathrm{CO}_{2}$ concentration was more pronounced.

Keywords: Zea mays L., global warming, DSSAT, root depth, mulching.

\section{MODELAGEM DE ESTRATÉGIAS DE MANEJO PARA MITIGAR OS EFEITOS DE ALTERAÇÕES NA TEMPERATURA E NA CONCENTRAÇÃO DE $\mathrm{CO}_{2}$ NO MILHO}

Resumo - As mudanças climáticas em curso podem afetar a produtividade do milho de sequeiro no Brasil as quais podem ser atenuadas por algumas estratégias de manejo. Este trabalho teve como objetivo avaliar, utilizando modelagem computacional, práticas de manejo com potencial para mitigar os efeitos de mudanças na temperatura e na concentração de $\mathrm{CO}_{2}$ na produtividade de milho. O modelo CSM-CERES-Maize foi aplicado para simular o potencial de mitigação do uso de cultivares de milho com profundidade de raiz de $0,3 \mathrm{~m}, 0,5 \mathrm{~m}$ e $0,7 \mathrm{~m}$, associado a $0 \mathrm{t} \mathrm{ha}^{-1}, 2 \mathrm{t} \mathrm{ha}^{-1}$ e $4 \mathrm{t} \mathrm{ha}^{-1}$ de palhada deixada na superfície do solo. Uma série com 33 anos de dados climáticos diários, juntamente com dados do perfil do solo, foram utilizados para avaliar a abordagem em 10 regiões do estado de Minas Gerais, Brasil. Para a maioria das regiões, o uso de palhada e de cultivar com sistema radicular mais profundo não foi capaz de atenuar o aumento da temperatura. Em contrapartida, qualquer fator que limita o crescimento radicular do milho a uma profundidade de $0,30 \mathrm{~m}$, provoca uma queda significativa na produtividade, mesmo em cenário de redução de $3{ }^{\circ} \mathrm{C}$ na temperatura ou de aumento da concentração de $\mathrm{CO}_{2}$. Nas regiões mais quentes e mais secas, a resposta positiva do milho ao aumento da concentração de $\mathrm{CO}_{2}$ foi mais pronunciada.

Palavras-chave: Zea mays L., aquecimento global, DSSAT, profundidade de raiz, palhada. 
Maize crop is of great relevance for the Brazilian agribusiness since it is a part of the grain export agenda in addition to supplying the domestic market. In the 2018/2019 cropping season the state of Minas Gerais, Brazil was the second largest maize producer as regards the first harvest, and the fifth when considering the two cropping seasons commonly practiced in the Center-South region of the country (Acompanhamento da Safra Brasileira [de] Grãos, 2020). Most of the maize production system runs under rainfed conditions, that is, therefore subject to climate instabilities, which cause inter-annual fluctuations in yield as registered by the Brazilian Institute of Geography and Statistics (IBGE, 2020). An aggravating factor to this problem is the ongoing climate changes (Intergovernmental Panel on Climate Change, 2014). The increase in the concentration of greenhouse gases GHGs in the earth's atmosphere, mainly $\mathrm{CO}_{2}$, besides the direct impact on some crop performance, causes changes especially in the air temperature (NASA, 2010).

Global agricultural yield is expected to reduce 17\% by 2050 (Assad et al., 2019). In tropical and subtropical regions of Africa and South America a reduction of $3 \mathrm{t} \mathrm{ha}^{-1}$ in crop yield is expected due to the increase in plant maintenance respiration and to the decrease in soil moisture, both in response to the rise in temperature (Levis et al., 2018). The increase in both $\mathrm{CO}_{2}$ concentration and temperature can affect maize production, either by individual or by combined effect (Maldaner et al., 2014). These effects can influence traits as phenology, diseases incidence, evapotranspiration rate and soil water availability.

Changes in temperature directly affect the growth and development of maize, whose minimum, optimal and maximum limits are, respectively, $8-10^{\circ} \mathrm{C}, 25-26^{\circ} \mathrm{C}$ to $30-34^{\circ} \mathrm{C}$ and $42-44^{\circ} \mathrm{C}$ (Kiniry et al., 1991; Cruz et al., 2011). In regions with warmer climate, such as in the tropics, the temperature often exceeds the optimum range for maize, resulting in a shortening of the vegetative and reproductive phases and an increase in the evapotranspiration rate that depletes the soil water more quickly and can affect yield (Levis et al., 2018; Lizaso et al., 2018; Souza et al., 2019). On the other hand, nighttime temperatures above $24^{\circ} \mathrm{C}$ increase the maintenance respiration, reduce photoassimilate accumulation, causing a drop in production (Sans and Santana, 2002). Low temperatures, in turn, reduce the rate of crop development and in some cases can even paralyze the entire process (Bergamaschi and Matzenauer, 2014; Cruz et al., 2011).

A modeling study on climate change carried out for the Midwest region of Brazil pointed out that, by the end of the 21 st century, there may be a 50 to $89 \%$ decrease in yield for the second (offseason) maize crop sowed late. The high temperatures shortened the crop cycle and reduced the water use efficiency (Andrea et al., 2019). In the United Sates, due to maize adaptation mechanisms, the increase in the air temperature has caused lower than expected yield drops, especially for irrigated crops (Butler and Huybers, 2013).

The increase in the atmospheric carbon dioxide $\left(\mathrm{CO}_{2}\right)$ concentration can be beneficial for the development of several plant species. It favors photosynthetic activity since this molecule is one of the substrates for the photosynthesis (Taiz and Zeiger, 2009). Due to the C4 mechanism of maize, the isolated effect of doubling the $\mathrm{CO}_{2}$ concentration is relatively small on yield, less than $4 \%$ (Lin et al., 2017). Deryng et al. (2016) argue that the impact of temperature rise on maize yield can be $60 \%$, compensated by concomitant increase of $\mathrm{CO}_{2}$ concentration. However, 
the increase in the concentration of GHGs, including $\mathrm{CO}_{2}$, favors temperature rise, which can compromise the crop development. Therefore, the combined effect of increasing $\mathrm{CO}_{2}$ concentration and temperature is complex and still requires studies (Hatfield et al., 2011).

Some crop management strategies can be used to mitigate the effects of climate change on maize yield, such as the no-tillage system (NTS), cultivars tolerant to water and temperature stresses (Chapman et al., 2012; Lin et al., 2017), chemical and physical correction of the soil profile and the use of crop residues as mulching (Moraes et al., 2016). The combined effect of these strategies makes crops more resilient to climate change.

Crop residue left on the soil surface in the notillage system plays an important role to mitigate climate change. It reflects a larger fraction of the incident solar radiation, helps regulate the soil temperature, reduces water evaporation, increases infiltration and in the long term favors soil water retention (Moraes et al., 2016). In a literature review, Ranaivoson et al. (2017) encountered that $8 \mathrm{tha}^{-1}$ of mulching to reduce by $30 \%$ the soil water evaporation and at least $2 \mathrm{t} \mathrm{ha}^{-1}$ to have the maximum effect of increasing water infiltration and reducing runoff and soil loss are required.

The performance of the root system has a great impact on the economy of commercial maize production due to its effect on yield under drought conditions, on the nutrient absorption efficiency (Bänziger et al., 2000) and on the resilience to soil pests. Changes in the architecture of the root system and in the water absorption of cropping systems with high plant population are correlated with the historical yield of maize elite cultivars in the United States (Hammer et al., 2009). Therefore, the root system traits are important to mitigate the effects of climate change, which may or not impose conditions of water and thermal stresses to the crops. Considering that anatomical and molecular traits contribute to root performance (Meister et al., 2014), there is a need to shape maize root for increased stress tolerance and higher yield in a changing climate (Gong et al., 2015).

Conventional experimentation to evaluate the response of crops to strategies with potential to mitigate the effect of climate change is timeconsuming and has a high cost due to intensive use of equipment and labor. Process-based models, which allow the assessment of different crop management scenarios associated with long-term climate databases, are appropriate tools to address the problem. Models, such as those of the Decision Support System for Agrotechnology Transfer, DSSAT, (Hoogenboom et al., 2019), have been used for decades to obtain information on genotype-environment-management interaction and, more recently, to assess the effects of climate change on agricultural crops (Rosenzweig et al., 2014). In a study carried out in the Piracicaba region, Brazil, Soler et al. (2007) evaluated the capability of the CSM-CERES-Maize to simulate growth, development and yield of four maize hybrids with different maturity periods, all sown offseason. Salmerón et al. (2014) used lysimeter and filed trial to parameterize and evaluate the CSM-CERES-maize under irrigation and Mediterranean conditions. Later on, the model was used to evaluate the impact of rotation of maize cover crops on nitrogen leaching for different soil types and irrigation management along with a 14 years rotation at the La Violada basin, Spain. Jing et al. (2016) used the CSM-CERES-Maize to consider gaps between potential and real yields seeking identifying management options to improve maize production in East Canada. Amaral et al. (2017) 
considered management strategies to improve maize silage production for family farmers in the region of Pelotas, Brazil. The seasonal analysis tool of the CSM-CERES-Maize was applied to evaluate rainfed maize biomass production.

For Brazil's conditions, little research (Souza et al., 2019; Magalhães et al., 2019) has addressed the problem of adapting maize crops to climate change, especially issues related to the use of crop management strategies. Thus, this work was proposed with the objective of evaluating, using computational modeling, crop management strategies with potential to mitigate the effects of changes in the air temperature and in the atmospheric $\mathrm{CO}_{2}$ concentration on maize crop performance.

\section{Material and Methods}

The CSM-CERES-Maize of the DSSAT (Hoogenboom et al., 2019) suite, version 4.6.1 (Hoogenboom et al., 2014), was used to assess the potential of crop management strategies to mitigate possible effects of climate change on maize yield. The simulations were performed for ten representative municipalities of the state of Minas Gerais, Brazil, which represent mesoregions with distinct characteristics of both soil and weather: Aimorés, Araçuaí, Janaúba, Lavras, Machado, Paracatu, Pompéu, Sete Lagoas, Uberaba and Viçosa.

To create the soil files required by the model, soil samples were collected on selected farms or at experimental stations of Federal Education Institutes located in each region to determine the physicohydric and chemical attributes of the soil profiles $(0-0.05 \mathrm{~m}$; 0.05-0.20 m; 0.20-0.40 m; 0.40-0.70 $\mathrm{m}$ and 0.70-1.00 m) (TABLE 1). A historical series containing 33 years (1981-2013) of daily weather data of each region was obtained from the National Institute of Meteorology (INMET), Brazil. The consistency of the series was analyzed and the missing data for a period of up to seven days were filled in by using the WeatherMan tool (Pickering et al., 1994) of DSSAT. Missing data for longer periods were filled in with data from nearby stations with similar elevation. Annual average of weather data and the elevation of the stations are shown on table 2 .

The model was previously parameterized and evaluated by using data from field trials carried out for the single-cross hybrid DKB390PRO at different places, with and without water stress (Andrade et al., 2016; Magalhães et al., 2019). The DKB390PRO is a short cycle hybrid widely used in several producing regions of the Minas Gerais state and Brazil (Dekalb, 2016). The calibration coefficients of the hybrid are presented on table 3 .

Preliminary simulations were run using the historical weather data series allowing establishing, for each region, the sowing date which provides the highest grain yield under rainfed conditions, as follows: September $12^{\text {th }}$ for Lavras, October $3^{\text {rd }}$ for Viçosa, October $10^{\text {th }}$ for Sete Lagoas, October $17^{\text {th }}$ for Aimorés, Araçuaí, Janaúba, Paracatu and Pompéu, October $31^{\text {st }}$ for Machado and January $2^{\text {nd }}$ for Uberaba. Afterwards, for each region, year and best sowing date, the seasonal analysis tool of DSSAT was used to simulate the effect of different management strategies on maize yield.

The simulations were programmed to start at 30 days before sowing so that the nitrogen and water balance in the soil better approaches real field conditions at the sowing date. Concerning the maize crop management, a inter-row spacing of $0.7 \mathrm{~m}$, a plant population of $68,000 \mathrm{ha}^{-1}$ and a sowing depth of $0.05 \mathrm{~m}$ were considered. More details on the crop 
Table 1. Attributes of the soil profile of different regions of the state of Minas Gerais, Brazil

\begin{tabular}{|c|c|c|c|c|c|c|c|c|c|c|c|c|}
\hline Municipality & Depth & $\begin{array}{c}\text { Lower } \\
\text { Limit of } \\
\text { Available } \\
\text { Water }\end{array}$ & $\begin{array}{c}\text { Upper } \\
\text { Limit of } \\
\text { Available } \\
\text { Water }\end{array}$ & $\begin{array}{l}\text { Upper } \\
\text { limit, } \\
\text { saturated }\end{array}$ & $\begin{array}{c}\text { Sat. } \\
\text { hydraulic } \\
\text { conductivity }\end{array}$ & $\begin{array}{c}\text { Bulk } \\
\text { density }\end{array}$ & $\begin{array}{c}\text { Organic } \\
\text { carbon }\end{array}$ & Clay & Silt & $\begin{array}{c}\text { Total } \\
\text { nitrogen }\end{array}$ & $\begin{array}{l}\mathrm{pH} \text { in } \\
\text { water }\end{array}$ & $\begin{array}{c}\text { Cation } \\
\text { exchange } \\
\text { capacity }\end{array}$ \\
\hline & (m) & $\left(\mathrm{cm}^{3} \mathrm{~cm}^{-3}\right)$ & $\left(\mathrm{cm}^{3} \mathrm{~cm}^{-3}\right)$ & $\left(\mathrm{cm}^{3} \mathrm{~cm}^{-3}\right)$ & $\left(\mathrm{cm} \mathrm{h}^{-1}\right)$ & $\left(\mathrm{g} \mathrm{cm}^{-3}\right)$ & $(\%)$ & $(\%)$ & $(\%)$ & $(\%)$ & & $\left(\mathrm{cmol} \mathrm{kg}^{-1}\right)$ \\
\hline \multirow{5}{*}{ Aimorés } & 0.05 & 0.166 & 0.286 & 0.512 & 23.10 & 1.20 & 1.48 & 29.00 & 38.00 & 0.19 & 5.40 & 4.70 \\
\hline & 0.20 & 0.203 & 0.355 & 0.464 & 28.87 & 1.37 & 1.19 & 31.00 & 39.00 & 0.14 & 4.70 & 4.20 \\
\hline & 0.40 & 0.204 & 0.295 & 0.391 & 11.55 & 1.56 & 0.74 & 30.00 & 22.00 & 0.14 & 5.60 & 4.90 \\
\hline & 0.70 & 0.058 & 0.091 & 0.466 & 13.86 & 1.36 & 0.15 & 10.00 & 10.00 & 0.10 & 6.30 & 0.30 \\
\hline & 1.00 & 0.122 & 0.204 & 0.332 & 16.84 & 1.77 & 0.07 & 18.00 & 11.00 & 0.10 & 6.40 & 2.80 \\
\hline \multirow{5}{*}{ Araçuaí } & 0.05 & 0.105 & 0.240 & 0.466 & 1.65 & 1.37 & 1.27 & 23.00 & 52.00 & 0.12 & 5.20 & 4.70 \\
\hline & 0.20 & 0.137 & 0.283 & 0.357 & 2.31 & 1.61 & 1.19 & 25.00 & 50.00 & 0.12 & 5.00 & 3.90 \\
\hline & 0.40 & 0.130 & 0.274 & 0.381 & 1.39 & 1.61 & 0.59 & 25.00 & 52.00 & 0.08 & 5.30 & 3.10 \\
\hline & 0.70 & 0.143 & 0.255 & 0.312 & 0.92 & 1.70 & 0.37 & 34.00 & 45.00 & 0.06 & 5.70 & 3.50 \\
\hline & 1.00 & 0.162 & 0.248 & 0.324 & 2.31 & 1.76 & 0.22 & 32.00 & 41.00 & 0.04 & 6.20 & 5.10 \\
\hline \multirow{5}{*}{ Janaúba } & 0.05 & 0.195 & 0.353 & 0.446 & 2.77 & 1.38 & 2.15 & 45.00 & 27.00 & 0.26 & 6.80 & 9.50 \\
\hline & 0.20 & 0.219 & 0.322 & 0.392 & 6.93 & 1.54 & 1.19 & 65.00 & 18.00 & 0.22 & 6.30 & 6.30 \\
\hline & 0.40 & 0.216 & 0.324 & 0.414 & 13.86 & 1.46 & 0.74 & 58.00 & 28.00 & 0.14 & 5.90 & 7.00 \\
\hline & 0.70 & 0.211 & 0.331 & 0.401 & 2.77 & 1.52 & 0.45 & 60.00 & 19.00 & 0.19 & 5.70 & 5.90 \\
\hline & 1.00 & 0.180 & 0.316 & 0.437 & 16.17 & 1.36 & 0.30 & 62.00 & 23.00 & 0.09 & 4.80 & 4.60 \\
\hline \multirow{5}{*}{ Lavras } & 0.05 & 0.179 & 0.337 & 0.551 & 47.68 & 1.03 & 2.65 & 61.00 & 11.00 & 0.17 & 6.80 & 5.60 \\
\hline & 0.20 & 0.207 & 0.321 & 0.542 & 32.51 & 1.10 & 1.44 & 62.00 & 8.00 & 0.09 & 5.50 & 1.70 \\
\hline & 0.40 & 0.201 & 0.326 & 0.562 & 23.84 & 1.05 & 1.14 & 67.00 & 6.00 & 0.07 & 5.30 & 1.10 \\
\hline & 0.70 & 0.205 & 0.329 & 0.593 & 39.02 & 1.01 & 0.91 & 66.00 & 8.00 & 0.07 & 5.80 & 1.10 \\
\hline & 1.00 & 0.197 & 0.280 & 0.602 & 43.35 & 0.93 & 0.68 & 67.00 & 7.00 & 0.05 & 5.10 & 0.60 \\
\hline \multirow{5}{*}{ Machado } & 0.05 & 0.187 & 0.344 & 0.570 & 7.22 & 1.04 & 2.19 & 59.00 & 8.00 & 0.15 & 6.00 & 3.50 \\
\hline & 0.20 & 0.226 & 0.337 & 0.510 & 16.62 & 1.19 & 1.29 & 64.00 & 9.00 & 0.10 & 5.20 & 1.80 \\
\hline & 0.40 & 0.228 & 0.332 & 0.530 & 30.34 & 1.11 & 0.99 & 71.00 & 3.00 & 0.08 & 5.80 & 1.80 \\
\hline & 0.70 & 0.251 & 0.361 & 0.537 & 13.00 & 1.14 & 0.83 & 69.00 & 6.00 & 0.06 & 5.40 & 1.70 \\
\hline & 1.00 & 0.221 & 0.332 & 0.605 & 43.35 & 0.98 & 0.68 & 71.00 & 6.00 & 0.06 & 6.00 & 1.70 \\
\hline
\end{tabular}


Table 1. Attributes of the soil profile of different regions of the state of Minas Gerais, Brazil. Continued...

\begin{tabular}{|c|c|c|c|c|c|c|c|c|c|c|c|c|}
\hline & 0.05 & 0.254 & 0.363 & 0.549 & 73.69 & 1.14 & 2.27 & 73.00 & 19.00 & 0.17 & 6.30 & 4.80 \\
\hline & 0.20 & 0.256 & 0.364 & 0.545 & 19.51 & 1.12 & 1.06 & 79.00 & 15.00 & 0.11 & 6.40 & 3.60 \\
\hline \multirow[t]{5}{*}{ Paracatu } & 0.40 & 0.248 & 0.357 & 0.576 & 26.01 & 1.06 & 0.99 & 81.00 & 15.00 & 0.10 & 6.60 & 3.10 \\
\hline & 0.70 & 0.231 & 0.344 & 0.590 & 32.51 & 1.00 & 0.68 & 81.00 & 14.00 & 0.08 & 5.70 & 2.20 \\
\hline & 1.00 & 0.238 & 0.340 & 0.596 & 7.22 & 1.00 & 0.60 & 78.00 & 16.00 & 0.08 & 5.20 & 1.60 \\
\hline & 0.05 & 0.243 & 0.359 & 0.502 & 55.44 & 1.25 & 2.23 & 61.00 & 36.00 & 0.18 & 5.80 & 3.00 \\
\hline & 0.20 & 0.222 & 0.333 & 0.507 & 97.02 & 1.17 & 1.27 & 61.00 & 36.00 & 0.14 & 6.10 & 2.10 \\
\hline \multirow[t]{5}{*}{ Pompéu } & 0.40 & 0.227 & 0.372 & 0.534 & 36.96 & 1.13 & 0.82 & 64.00 & 34.00 & 0.19 & 5.50 & 0.70 \\
\hline & 0.70 & 0.243 & 0.397 & 0.505 & 27.72 & 1.19 & 0.59 & 67.00 & 31.00 & 0.10 & 5.20 & 0.30 \\
\hline & 1.00 & 0.232 & 0.349 & 0.548 & 41.58 & 1.11 & 0.59 & 66.00 & 33.00 & 0.14 & 5.20 & 0.00 \\
\hline & 0.05 & 0.191 & 0.300 & 0.611 & 46.46 & 0.91 & 3.45 & 68.00 & 18.00 & 0.37 & 6.10 & 6.00 \\
\hline & 0.20 & 0.249 & 0.362 & 0.551 & 38.83 & 1.05 & 1.72 & 77.00 & 9.00 & 0.30 & 6.00 & 2.70 \\
\hline \multirow[t]{5}{*}{ Sete Lagoas } & 0.40 & 0.234 & 0.359 & 0.583 & 13.88 & 0.97 & 0.97 & 79.00 & 9.00 & 0.14 & 5.90 & 1.80 \\
\hline & 0.70 & 0.229 & 0.354 & 0.605 & 21.26 & 0.93 & 0.82 & 79.00 & 8.00 & 0.35 & 5.60 & 2.50 \\
\hline & 1.00 & 0.168 & 0.276 & 0.604 & 18.74 & 0.91 & 0.75 & 81.00 & 5.00 & 0.65 & 5.50 & 0.90 \\
\hline & 0.05 & 0.110 & 0.254 & 0.439 & 10.84 & 1.50 & 1.06 & 24.00 & 6.00 & 0.07 & 5.20 & 0.80 \\
\hline & 0.20 & 0.117 & 0.263 & 0.432 & 13.44 & 1.52 & 0.38 & 27.00 & 7.00 & 0.04 & 5.50 & 0.50 \\
\hline \multirow[t]{5}{*}{ Uberaba } & 0.40 & 0.110 & 0.238 & 0.510 & 23.41 & 1.32 & 0.60 & 29.00 & 6.00 & 0.04 & 5.60 & 0.30 \\
\hline & 0.70 & 0.113 & 0.251 & 0.534 & 15.61 & 1.26 & 0.68 & 31.00 & 4.00 & 0.04 & 5.50 & 0.20 \\
\hline & 1.00 & 0.127 & 0.280 & 0.517 & 12.14 & 1.30 & 0.38 & 33.00 & 6.00 & 0.04 & 5.70 & 0.20 \\
\hline & 0.05 & 0.227 & 0.336 & 0.513 & 25.34 & 1.20 & 1.28 & 50.00 & 8.00 & 0.49 & 5.40 & 2.90 \\
\hline & 0.20 & 0.263 & 0.354 & 0.437 & 5.72 & 1.42 & 0.67 & 46.00 & 10.00 & 0.37 & 5.50 & 1.90 \\
\hline \multirow[t]{3}{*}{ Viçosa } & 0.40 & 0.286 & 0.372 & 0.498 & 6.85 & 1.27 & 0.52 & 57.00 & 10.00 & 0.68 & 5.60 & 2.60 \\
\hline & 0.70 & 0.310 & 0.411 & 0.466 & 61.19 & 1.28 & 0.75 & 62.00 & 7.00 & 0.67 & 5.70 & 1.80 \\
\hline & 1.00 & 0.346 & 0.461 & 0.466 & 5.71 & 1.29 & 0.67 & 64.00 & 11.00 & 0.67 & 5.50 & 1.20 \\
\hline
\end{tabular}

Table 2. Elevation of the weather station, average minimum and maximum temperatures, average temperature and annual rainfall over a period of 33 years (1981-2013) for regions of the state of Minas Gerais, Brazil.

\begin{tabular}{cccccc}
\hline Region & $\begin{array}{c}\text { Elevation of the } \\
\text { Weather Station }\end{array}$ & $\begin{array}{c}\text { Average Minimum } \\
\text { Temperature of 33 } \\
\text { Years }\end{array}$ & $\begin{array}{c}\text { Average } \\
\text { Maximum } \\
\text { Temperature of 33 } \\
\text { Years }\end{array}$ & $\begin{array}{c}\text { Average } \\
\text { Temperature of 33 } \\
\text { Years }\end{array}$ & $\begin{array}{c}\text { Average Annual } \\
\text { Rainfall of 33 } \\
\text { Years }\end{array}$ \\
\cline { 2 - 6 } & $(\mathrm{m})$ & $\left({ }^{\circ} \mathrm{C}\right)$ & $\left({ }^{\circ} \mathrm{C}\right)$ & $\left({ }^{\circ} \mathrm{C}\right)$ & $(\mathrm{mm})$ \\
\hline Aimorés & 83 & 20.3 & 31.8 & 26.1 & 976 \\
Araçuá & 289 & 19.6 & 31.8 & 25.7 & 757 \\
Janaúba & 516 & 18.9 & 31.4 & 25.2 & 811 \\
Lavras & 919 & 15.1 & 27.3 & 21.2 & 1491 \\
Machado & 873 & 14.5 & 27.4 & 21.0 & 1257 \\
Paracatu & 712 & 18.2 & 29.9 & 24.1 & 1483 \\
Pompéu & 691 & 16.9 & 29.8 & 23.4 & 1244 \\
Sete Lagoas & 732 & 15.1 & 27.3 & 21.2 & 1491 \\
Uberaba & 737 & 16.8 & 29.4 & 23.1 & 1660 \\
Viçosa & 712 & 15.8 & 26.9 & 21.4 & 1337 \\
\hline
\end{tabular}

Revista Brasileira de Milho e Sorgo, v.20, e1210, 2021

DOI: https://doi.org/10.18512/rbms2021v20e1210 
Table 3. Calibrated parameters of the CSM-CERES-Maize for the single-cross hybrid, DKB390PRO.

\begin{tabular}{|c|c|c|c|}
\hline $\begin{array}{c}\text { Model's } \\
\text { Parameter }\end{array}$ & Description & Unit & $\begin{array}{l}\text { Calibrated } \\
\text { Value }\end{array}$ \\
\hline $\mathrm{P} 1$ & $\begin{array}{l}\text { Thermal sum from emergency to the end of the juvenile } \\
\text { phase }\end{array}$ & Degree-Day & 263 \\
\hline $\mathrm{P} 2$ & Sensitivity to photoperiod & Day & 0.5 \\
\hline P5 & Thermal sum between flowering and physiological maturity & Degree-Day & 1087 \\
\hline G2 & Maximum number of grains per plant & Number & 713 \\
\hline G3 & Potential rate of grain filling. & $\mathrm{Mg} \mathrm{day}^{-1}$ & 4.97 \\
\hline PHINT & Thermal sum required for successive appearance of leaves. & Degree-Day & 45.50 \\
\hline
\end{tabular}

management were reported by Magalhães et al. (2019).

The model was set to simulate different scenarios of crop management strategies that present the potential to mitigate the effects of climate change, as follows: (Rz30) - A cultivar with a root system predominantly concentrated on the $0-0.30 \mathrm{~m}$ layer of the soil profile, equivalent to a cultivar with low tolerance to $\mathrm{Al}^{3+}$ and to low $\mathrm{pH}$, a typical condition found in an acidic soil that was not properly corrected for $\mathrm{Al}^{3+}$ and $\mathrm{pH}$. These conditions represent an indirect effect, since the model does not simulate the effect of soil acidity on yield; (Rz50) - A cultivar with a root system predominantly concentrated on the $0-0.50 \mathrm{~m}$ layer of the soil profile; this is the standard or baseline scenario, typical of a maize crop grown on the Brazilian cerrado; (Rz70) - A cultivar with a root system predominantly concentrated on the $0-0.70 \mathrm{~m}$ layer of the soil profile; this condition represents the use of an improved cultivar with a deeper root system or a very well-corrected soil profile; this is also an indirect effect as previously explained; (Cob0) - An inadequate no-tillage system that does not leave crop residue or mulching on the soil surface; (Cob2) - A reasonable-managed no-tillage system that leaves $2 \mathrm{t}$ $\mathrm{ha}^{-1}$ of crop residue or mulching on the soil surface; this represents the standard or baseline scenario; (Cob4) - A well-managed no-till system that leaves 4 $\mathrm{t} \mathrm{ha}^{-1}$ of crop residue or mulching on the soil surface.

The DSSAT was also programmed to alter the observed data of minimum and maximum air temperature and the atmospheric carbon dioxide concentrations $\left(\mathrm{CO}_{2}\right)$, as follows: (T-3) - Minimum and maximum air temperature $3{ }^{\circ} \mathrm{C}$ lower than the baseline; (T-0) - No change in the minimum and maximum air temperature (baseline); $(\mathrm{T}+3)$ Minimum and maximum air temperature $3{ }^{\circ} \mathrm{C}$ higher than the baseline; $(\mathrm{T}+6)$ - Minimum and maximum air temperature $6{ }^{\circ} \mathrm{C}$ higher than the baseline; (T+9) Minimum and maximum air temperature $9{ }^{\circ} \mathrm{C}$ higher 
than the baseline; $(\mathrm{CO} 2350)-\mathrm{CO}_{2}$ concentration of 350 ppmv; (CO2380) - $\mathrm{CO}_{2}$ concentration of 380 ppmv (baseline); $(\mathrm{CO} 2450)-\mathrm{CO}_{2}$ concentration of 450 ppmv; (CO2550) - $\mathrm{CO}_{2}$ concentration of 550 ppmv; (CO2650) - $\mathrm{CO}_{2}$ concentration of 650 ppmv; $(\mathrm{CO} 2750)-\mathrm{CO}_{2}$ concentration of $750 \mathrm{ppmv}$.

The variation of the values for the maximum and minimum air temperature and for the $\mathrm{CO}_{2}$ atmospheric concentration follow the protocol of the Agricultural Model Intercomparison and Improvement Project, AgMIP (Rosenzweig et al., 2013). Annual average of observed and altered temperature values of each study region are presented in table 4.

The combination of five levels of air temperature with three root system depths and with three amounts of crop residue left on the surface resulted in 45 scenarios for each one of the ten study regions. Similarly, the six $\mathrm{CO}_{2}$ concentration levels, associated with the three root systems and with the three mulching treatments resulted in 54 scenarios for each region. Simulated results were compared to assess whether or not the crop management strategies were effective to mitigate the effects of climate changes on maize crop performance. The 45 treatments of air temperature and the 54 treatments of $\mathrm{CO}_{2}$ concentration, versus the crop management strategies, were statistically compared using analysis of variance (ANOVA) in a factorial scheme in a randomized block design. Each one of the 33 simulated yield values for each year was considered a replication. Average comparisons were performed by the Tukey test at 5\% probability. Each region was evaluated individually, comparing their treatments (scenarios). The ANOVA and mean comparisons were performed using the software SISVAR 5.6 (Ferreira, 2011).

Table 4. Average annual values of observed temperature (T0) and of altered temperature for each study region.

\begin{tabular}{cccccc}
\hline & \multicolumn{5}{c}{ Average Temperature of 33 Years $\left({ }^{\circ} \mathbf{C}\right)$} \\
\cline { 2 - 5 } Region & \multicolumn{5}{c}{ Scenarios } \\
\cline { 2 - 5 } & $\mathbf{T}-3$ & $\mathbf{T 0}$ & $\mathbf{T}+\mathbf{3}$ & $\mathbf{T}+\mathbf{6}$ & $\mathbf{T + 9}$ \\
\hline Aimorés & 23.1 & 26.1 & 29.1 & 32.1 & 35.1 \\
Araçuaí & 22.7 & 25.7 & 28.7 & 31.7 & 34.7 \\
Janaúba & 22.2 & 25.2 & 28.2 & 31.2 & 34.2 \\
Lavras & 18.2 & 21.2 & 24.2 & 27.2 & 30.2 \\
Machado & 18.0 & 21.0 & 24.0 & 27.0 & 30.0 \\
Paracatu & 21.1 & 24.1 & 27.1 & 30.1 & 33.1 \\
Pompéu & 20.4 & 23.4 & 23.4 & 29.4 & 32.4 \\
Sete Lagoas & 18.2 & 21.2 & 24.2 & 27.2 & 30.2 \\
Uberaba & 20.1 & 23.1 & 26.1 & 29.1 & 32.1 \\
Viçosa & 18.4 & 21.4 & 24.4 & 27.4 & 30.4 \\
\hline
\end{tabular}




\section{Results and Discussion}

\section{Crop Management Strategies versus Change in the Air Temperature}

Statistical analyses indicated that no significant interaction, at $5 \%$ probability level, was found between depth of the root system, temperature and amount of residue left on the soil surface and also between depth of the root system and amount of residue in any of the study regions. However, the interactions between crop residue and temperature and between root depth and temperature were significant. Those were unfolded and the Tukey test at 5\% probability was applied to evaluate the effects on maize yield (tables 5 and 6).

The only region that showed significant interaction between the amount of crop residue and changes in temperature was Araçuaí (table 5). For scenarios with no change in temperature (T0) or with a reduction of $3^{\circ} \mathrm{C}(\mathrm{T}-3)$, the maintenance on the soil surface of 2 or $4 \mathrm{tha}^{-1}$ of residue showed a beneficial and significant effect on yield, as compared to the scenario without mulching. Crop residues left on the soil surface in the no-tillage system reflect a greater fraction of the incident solar radiation, help with thermal regulation, reduce water evaporation, increase infiltration and favor water retention in the soil (Moraes et al., 2016). In the scenario of a $3^{\circ} \mathrm{C}(\mathrm{T}+3)$ increase in temperature, a significant difference was determined only when the amount of crop residue was increased from 0 to $4 \mathrm{tha}^{-1}$. On the other hand, for the other scenarios of temperature levels $(\mathrm{T}+6$ and $\mathrm{T}+9)$, it was found that the yield did not differ statistically for the amounts of residue left on the soil surface. At these high levels of temperature increase, the use of crop residue did not mitigate the effects on yield, due to shortening of maize cycle (Figure 1) and possibly because soilwater evaporation was not sufficiently reduced (Ranaivoson et al., 2017). Still in Araçuaí, it was noted that, regardless of the amount of crop residue left on the soil surface, maize yield was significantly affected by all changes in the air temperature (table 5).

The regions of Araçuaí, Janaúba, Lavras, Machado, Paracatu, Pompéu, Sete Lagoas, Uberaba and Viçosa showed significant interaction between changes in temperature and root system depth. In all

Table 5. Comparison of maize yields $\left(\mathrm{kg} \mathrm{ha}^{-1}\right)$ for different levels of temperature and amounts of crop residue on the soil surface for Araçuaí, Brazil.

\begin{tabular}{ccccc}
\hline \multirow{2}{*}{ Region } & \multirow{2}{*}{$\begin{array}{c}\text { Temperature } \\
\text { Change }\end{array}$} & \multicolumn{3}{c}{${\text { Amount of Crop Residue (t } \mathbf{~ h a}^{-1} \text { ) }}$} \\
\cline { 3 - 5 } & $\mathrm{T}-3$ & $5080 \mathrm{Aa}$ & $\mathbf{2}$ & $\mathbf{4}$ \\
\hline \multirow{3}{*}{ Araçuaí } & $\mathrm{T} 0$ & $4365 \mathrm{Ab}$ & $4893 \mathrm{Ba}$ & $6112 \mathrm{Ba}$ \\
& $\mathrm{T}+3$ & $2462 \mathrm{Ac}$ & $2730 \mathrm{ABc}$ & $5097 \mathrm{Bb}$ \\
& $\mathrm{T}+6$ & $748 \mathrm{Ad}$ & $844 \mathrm{Ad}$ & $2858 \mathrm{Bc}$ \\
& $\mathrm{T}+9$ & $33 \mathrm{Ae}$ & $36 \mathrm{Ae}$ & $887 \mathrm{Ad}$ \\
& & & $38 \mathrm{Ae}$ \\
\hline
\end{tabular}

Values followed by the same upper-case letter, in the line, and lower-case letter, in the column, do not differ statistically from each other by the Tukey test at $5 \%$ probability. 




Figure 1 - Maize crop cycle for different scenarios of temperature and regions of the state of Minas Gerais, Brazil.

of these regions and for all scenarios of temperature change, the deepening of the maize root system from $0.5 \mathrm{~m}$ to $0.7 \mathrm{~m}$ did not provide significant differences in yield (table 6). In contrast, any factor that limited the growth of the root system to $0.30 \mathrm{~m}$ depth, caused statistically significant reductions in yield for scenarios $\mathrm{T}-3, \mathrm{~T} 0$ and $\mathrm{T}+3$, in all regions, except Araçuaí and Viçosa. This reinforces the importance of the adequate correction of soil profile as a mitigation measure to cope with climate change. In Araçuaí, a significant effect on yield of reducing the root depth from $0.5 \mathrm{~m}$ to $0.3 \mathrm{~m}$ was obtained only in the scenarios $\mathrm{T} 0$ and T-3, while in Viçosa this occurred only for the temperature reduction scenario (T-3). No significant effect of the root depth on yield was observed for the scenarios T+6 e T+9 in Araçuaí, Janaúba, Machado, Uberaba and Viçosa, while in Lavras, Paracatu, Pompéu and Sete Lagoas this trend was only verified for the scenario $\mathrm{T}+9$ (table 6 ).

The root system is of great relevance in commercial maize production due to its influence on yield under drought conditions and also on the efficiency of nutrient absorption (Bänziger et al., 2000). In dense crops of maize in the United States, changes in the root system architecture and in the water absorption are correlated with the historical 
Table 6. Comparison of maize yields $\left(\mathrm{kg} \mathrm{ha}^{-1}\right)$ for different levels of temperature and depths of maize root system for the regions of study, Brazil.

\begin{tabular}{|c|c|c|c|c|}
\hline \multirow{2}{*}{ Regions } & \multirow{2}{*}{$\begin{array}{c}\text { Temperature } \\
\text { Change }\end{array}$} & \multicolumn{3}{|c|}{ Depth of Maize Root System (m) } \\
\hline & & 0.3 & 0.5 & 0.7 \\
\hline \multirow{5}{*}{ Araçuaí } & $\mathrm{T}-3$ & $5277 \mathrm{Aa}$ & 6042Ba & $5766 \mathrm{Ba}$ \\
\hline & T0 & $4366 \mathrm{Ab}$ & $5017 \mathrm{Bb}$ & $4983 \mathrm{Bb}$ \\
\hline & $\mathrm{T}+3$ & 2487Ac & 2772Ac & $2790 \mathrm{Ac}$ \\
\hline & $\mathrm{T}+6$ & 778Ad & 844Ad & 857Ad \\
\hline & $\mathrm{T}+9$ & $35 \mathrm{Ae}$ & $36 \mathrm{Ae}$ & $36 \mathrm{Ae}$ \\
\hline \multirow{5}{*}{ Janaúba } & $\mathrm{T}-3$ & 4464Aa & $6301 \mathrm{Ba}$ & $6431 \mathrm{Ba}$ \\
\hline & T0 & $4205 \mathrm{Aa}$ & $5344 \mathrm{Bb}$ & $5414 \mathrm{Bb}$ \\
\hline & $\mathrm{T}+3$ & $2603 \mathrm{Ab}$ & 3289Bc & 3337Bc \\
\hline & $\mathrm{T}+6$ & $983 \mathrm{Ac}$ & 1276Ad & $1295 \mathrm{Ad}$ \\
\hline & $\mathrm{T}+9$ & $124 \mathrm{Ad}$ & $156 \mathrm{Ae}$ & $159 \mathrm{Ae}$ \\
\hline \multirow{5}{*}{ Lavras } & $\mathrm{T}-3$ & 9020Aa & $11019 \mathrm{Ba}$ & $10902 \mathrm{Ba}$ \\
\hline & T0 & $8140 \mathrm{Ab}$ & $9327 \mathrm{Bb}$ & $9360 \mathrm{Bb}$ \\
\hline & $\mathrm{T}+3$ & 5997Ac & $6846 \mathrm{Bc}$ & $6920 \mathrm{Bc}$ \\
\hline & $\mathrm{T}+6$ & 3538Ad & $4058 \mathrm{Bd}$ & $4116 \mathrm{Bd}$ \\
\hline & $\mathrm{T}+9$ & $1164 \mathrm{Ae}$ & $1369 \mathrm{Ae}$ & $1385 \mathrm{Ae}$ \\
\hline \multirow{5}{*}{ Machado } & $\mathrm{T}-3$ & 9199Aa & $10102 \mathrm{Ba}$ & $10111 \mathrm{Ba}$ \\
\hline & T0 & $7767 \mathrm{Ab}$ & $8383 \mathrm{Bb}$ & $8437 \mathrm{Bb}$ \\
\hline & $\mathrm{T}+3$ & $5684 \mathrm{Ac}$ & $6121 \mathrm{Bc}$ & $6181 \mathrm{Bc}$ \\
\hline & $\mathrm{T}+6$ & $3517 \mathrm{Ad}$ & 3769Ad & $3811 \mathrm{Ad}$ \\
\hline & $\mathrm{T}+9$ & 1134Ae & $1220 \mathrm{Ae}$ & 1236Ae \\
\hline \multirow{5}{*}{ Paracatu } & $\mathrm{T}-3$ & 7204Aa & 9097Ba & $9113 \mathrm{Ba}$ \\
\hline & T0 & $6650 \mathrm{Ab}$ & $7719 \mathrm{Bb}$ & $7744 \mathrm{Bb}$ \\
\hline & $\mathrm{T}+3$ & 4606Ac & $5340 \mathrm{Bc}$ & $5402 \mathrm{Bc}$ \\
\hline & $\mathrm{T}+6$ & $1934 \mathrm{Ad}$ & $2377 \mathrm{Bd}$ & $2416 \mathrm{Bd}$ \\
\hline & $\mathrm{T}+9$ & $360 \mathrm{Ae}$ & $441 \mathrm{Ae}$ & $451 \mathrm{Ae}$ \\
\hline \multirow{5}{*}{ Pompéu } & $\mathrm{T}-3$ & $8571 \mathrm{Aa}$ & $9475 \mathrm{Ba}$ & $9470 \mathrm{Ba}$ \\
\hline & T0 & $7448 \mathrm{Ab}$ & $8235 \mathrm{Bb}$ & $8251 \mathrm{Bb}$ \\
\hline & $\mathrm{T}+3$ & 4955Ac & $5508 \mathrm{Bc}$ & $5558 \mathrm{Bc}$ \\
\hline & $\mathrm{T}+6$ & $2015 \mathrm{Ad}$ & 2426Bd & $2454 \mathrm{Bd}$ \\
\hline & $\mathrm{T}+9$ & $394 \mathrm{Ae}$ & 459Ae & $460 \mathrm{Ae}$ \\
\hline \multirow{5}{*}{ Sete Lagoas } & $\mathrm{T}-3$ & 7729Aa & $10043 \mathrm{Ba}$ & $10065 \mathrm{Ba}$ \\
\hline & T0 & 7436Aa & $8559 \mathrm{Bb}$ & $8569 \mathrm{Bb}$ \\
\hline & $\mathrm{T}+3$ & $5332 \mathrm{Ab}$ & $6355 \mathrm{Bc}$ & $6395 \mathrm{Bc}$ \\
\hline & $\mathrm{T}+6$ & 2992Ac & 3483Bd & $3523 \mathrm{Bd}$ \\
\hline & $\mathrm{T}+9$ & 807Ad & $965 \mathrm{Ae}$ & 978Ae \\
\hline \multirow{5}{*}{ Uberaba } & T-3 & $8627 \mathrm{Aa}$ & $11641 \mathrm{Ba}$ & $11316 \mathrm{Ba}$ \\
\hline & T0 & 8439Aa & $9549 \mathrm{Bb}$ & $9456 \mathrm{Bb}$ \\
\hline & $\mathrm{T}+3$ & $6550 \mathrm{Ab}$ & 6988Bc & $6981 \mathrm{Bc}$ \\
\hline & $\mathrm{T}+6$ & $3195 \mathrm{Ac}$ & $3501 \mathrm{Ad}$ & $3502 \mathrm{Ad}$ \\
\hline & $\mathrm{T}+9$ & $612 \mathrm{Ad}$ & 706Ae & $707 \mathrm{Ae}$ \\
\hline \multirow{5}{*}{ Viçosa } & $\mathrm{T}-3$ & 7264Aa & $8090 \mathrm{Ba}$ & 8149Ba \\
\hline & T0 & $6436 \mathrm{Ab}$ & $6745 \mathrm{ABb}$ & $6851 \mathrm{Bb}$ \\
\hline & $\mathrm{T}+3$ & 4662Ac & 4918Abc & $5080 \mathrm{Bc}$ \\
\hline & $\mathrm{T}+6$ & $2345 \mathrm{Ad}$ & $2515 \mathrm{Ad}$ & $2700 \mathrm{Ad}$ \\
\hline & $\mathrm{T}+9$ & 778Ae & $806 \mathrm{Ae}$ & $867 \mathrm{Ae}$ \\
\hline
\end{tabular}

Values followed by the same upper-case letter, in the line, and lower-case, in the column, do not differ statistically from each other by the Tukey test at $5 \%$ probability. 
yield of elite cultivars (Hammer et al., 2009). In Brazil, the inadequate management of the no-tillage system has led to the formation of a compacted layer at $0.1 \mathrm{~m}$ to $0.2 \mathrm{~m}$ depth (Franchini et al., 2011), which can affect root growth (Labegalini et al., 2016) and ultimately compromise the maize yield. In the no-tillage system, more than $97 \%$ of the roots were found in the 0 to $0.2 \mathrm{~m}$ deep layer (Rodrigues et al., 2017), which can increase the crop's vulnerability to water stress, especially undeer conditions of increased air temperature.

It can found that maize responded strongly to changes in the minimum and maximum air temperatures, irrespective of the study region (Figure $2)$. The reduction of $3^{\circ} \mathrm{C}(\mathrm{T}-3)$ in the air temperature, for the baseline management scenario (Rz50Cob2), provided an yield increase of $28 \%$ in Aimorés, $21 \%$ in Araçuaí, $18 \%$ in Janaúba, $18 \%$ in Lavras and 20\% in Machado. On the other hand, a rise of $3^{\circ} \mathrm{C}(\mathrm{T}+3)$, for the same crop management scenario (Rz50Cob2), caused a $54 \%, 45 \%, 38 \%, 26 \%$ and $27 \%$ yield reduction in the same regions, respectively (Figure 2). The over-response of maize crop to the $3{ }^{\circ} \mathrm{C}$ rise in the temperature as compared to the reduction of the same magnitude is evident. The effect of temperature rise on maize yield was stronger in warmer regions where temperature is already high (tables 2 and 4).

In the scenario with deeper root system and greater amount of crop residue on the soil surface (Rz70Cob4), Aimorés showed a yield reduction of 53\%, while in Araçuaí the decrease was 42\% (Figures 2A and 2B). Lavras and Machado presented a yield drop of $24 \%$ and $25 \%$, respectively (Figures $2 \mathrm{D}$ and $2 \mathrm{E}$ ). The reduction in maize yield was even more drastic for the scenarios of increasing $6{ }^{\circ} \mathrm{C}(\mathrm{T}+6)$ and $9{ }^{\circ} \mathrm{C}(\mathrm{T}+9)$ in temperature (Figure 2). Yield breaks of $91 \%$ and $82 \%$ were simulated in Aimorés and Araçuaí, respectively, for the $\mathrm{T}+6$ scenario, reaching a $100 \%$ drop in Aimorés for the $\mathrm{T}+9$ scenario (Figures $2 \mathrm{~A}$ and $2 \mathrm{~B}$ ). This sharp decrease in yield was obtained even for the scenario that represents a well-corrected soil profile, without restriction on root growth (Rz70) and with a well-established no-till system that leaves $4 \mathrm{t} \mathrm{ha}^{-1}$ of crop residue on the soil surface (Cob4). Even in regions with a mild climate, as in Machado (tables 2 and 4), with a good amount of crop residue left on the soil surface and a root system growing without limitations (Rz70Cob4), the drop in yield may exceed $50 \%$ and $80 \%$, for scenarios $\mathrm{T}+6$ and $\mathrm{T}+9$, respectively (Figure 2E).

Overall, deepening the maize root system and increasing the amount of crop residue on the soil surface, beyond the current levels of crop system management, did little to mitigate the drop in yield in response to increased air temperature. In fact, Ranaivoson et al. (2017) reported that $8 \mathrm{t}$ $\mathrm{ha}^{-1}$ of crop residue is needed to reduce the soilwater evaporation by $30 \%$, which could mitigate the effect of increasing air temperature. On the Brazilian cerrado, a simulation study done for the municipality of Planaltina reported small impact of the crop residue left on the soil surface on the water availability for maize. However, the same work showed that in a semi-arid ecosystem, with high variability in the rainfall regime, the maintenance of a small amount of residue on the soil surface has been shown to be effective in reducing runoff and soil-water evaporation, providing greater yield and less risk of maize yield break (Scopel et al., 2004).

A modeling study on climate change conducted for the Midwest region of Brazil, pointed out that at the end of the 21 st century there may be a $50 \%$ to $89 \%$ decrease in maize yield for late-sowing in the second crop season (Andrea et al., 2019). On the other hand, due to the adaptation mechanisms 


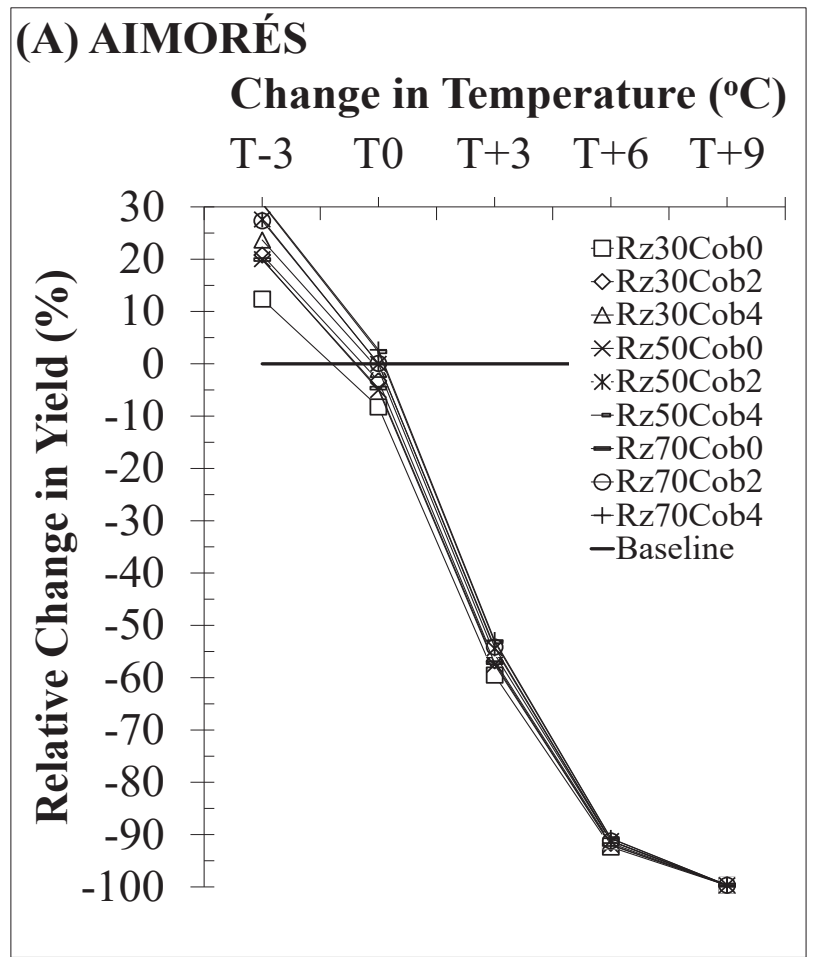

(C) JANAÚBA

Change in Temperature $\left({ }^{\circ} \mathrm{C}\right)$ $\mathrm{T}-3 \quad \mathrm{~T} 0 \quad \mathrm{~T}+3 \quad \mathrm{~T}+6 \quad \mathrm{~T}+9$

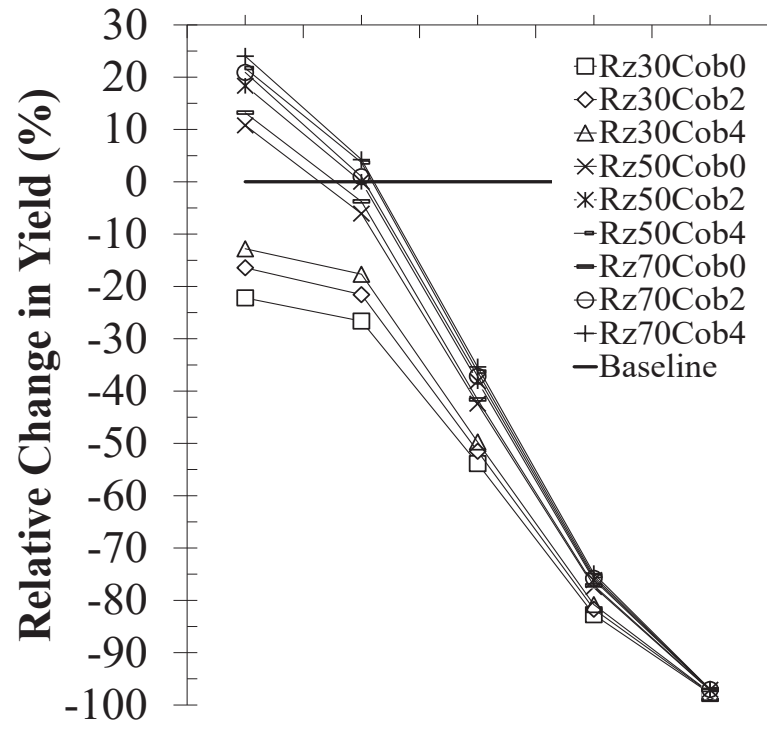

(B) ARAÇUAÍ

Change in Temperature $\left({ }^{\circ} \mathrm{C}\right)$ $\mathrm{T}-3 \quad \mathrm{~T} 0 \quad \mathrm{~T}+3 \quad \mathrm{~T}+6 \quad \mathrm{~T}+9$

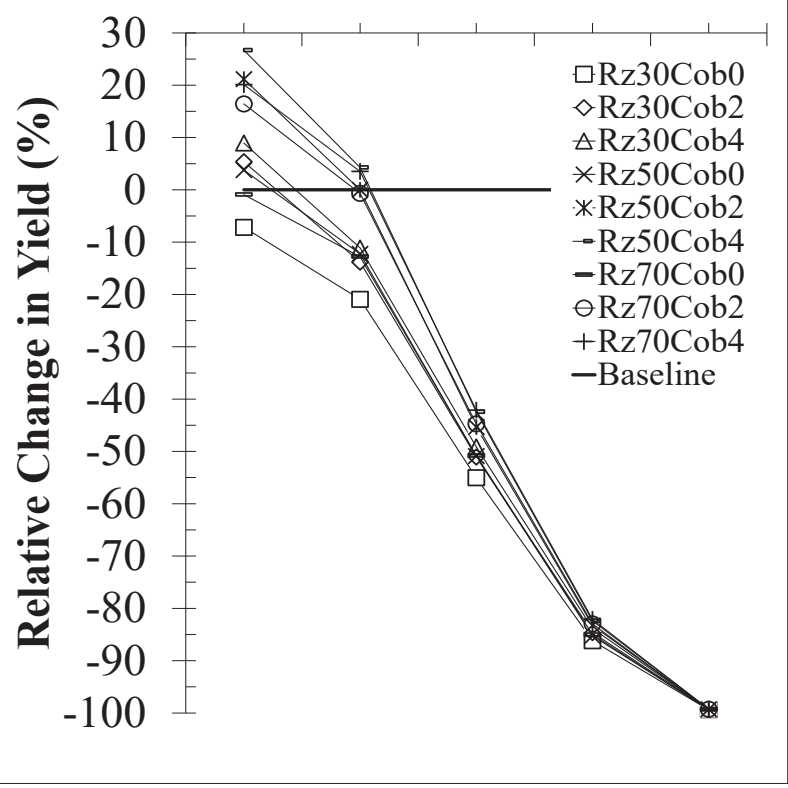

(D) LAVRAS

Change in Temperature $\left({ }^{\circ} \mathrm{C}\right)$ $\mathrm{T}-3 \quad \mathrm{~T} 0 \quad \mathrm{~T}+3 \quad \mathrm{~T}+6 \quad \mathrm{~T}+9$

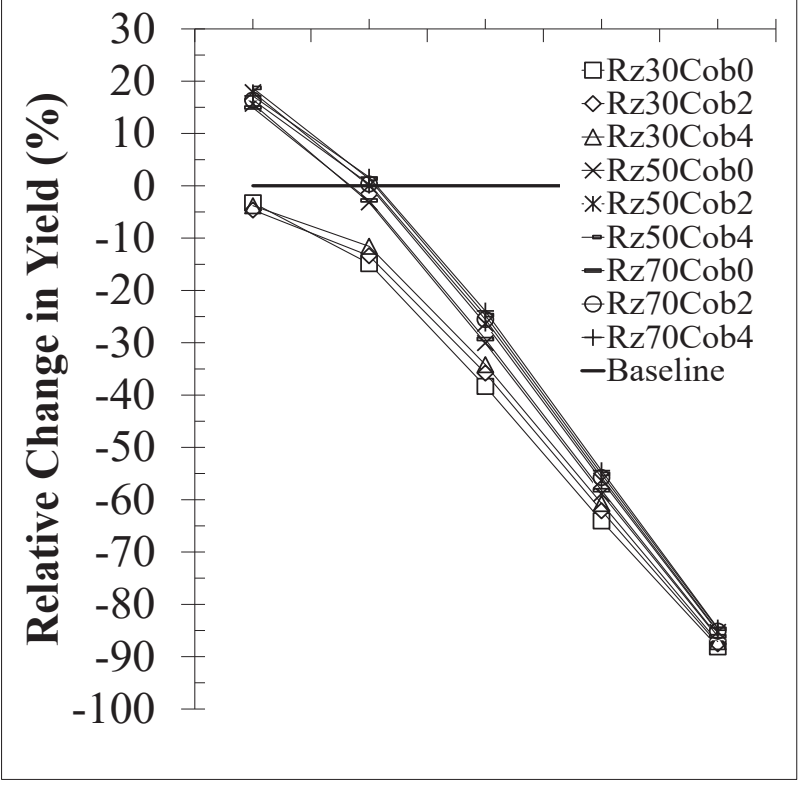

Figure 2 - Relative change in maize yield for different scenarios of temperature and of crop management strategies. 
(E) MACHADO

Change in Temperature $\left({ }^{\circ} \mathrm{C}\right)$



(G) POMPÉU

Change in Temperature $\left({ }^{\circ} \mathrm{C}\right)$

$\mathrm{T}-3 \quad \mathrm{~T} 0 \quad \mathrm{~T}+3 \quad \mathrm{~T}+6 \quad \mathrm{~T}+9$

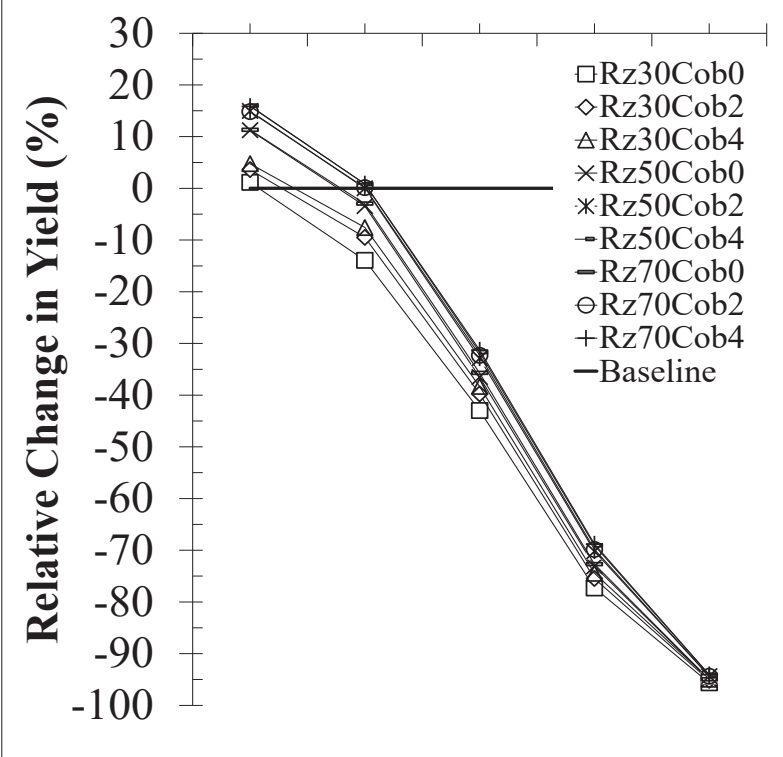

(F) PARACATU

Change in Temperature $\left({ }^{\circ} \mathrm{C}\right)$

$\begin{array}{ccccc}\mathrm{T}-3 & \mathrm{~T} 0 & \mathrm{~T}+3 & \mathrm{~T}+6 & \mathrm{~T}+9\end{array}$

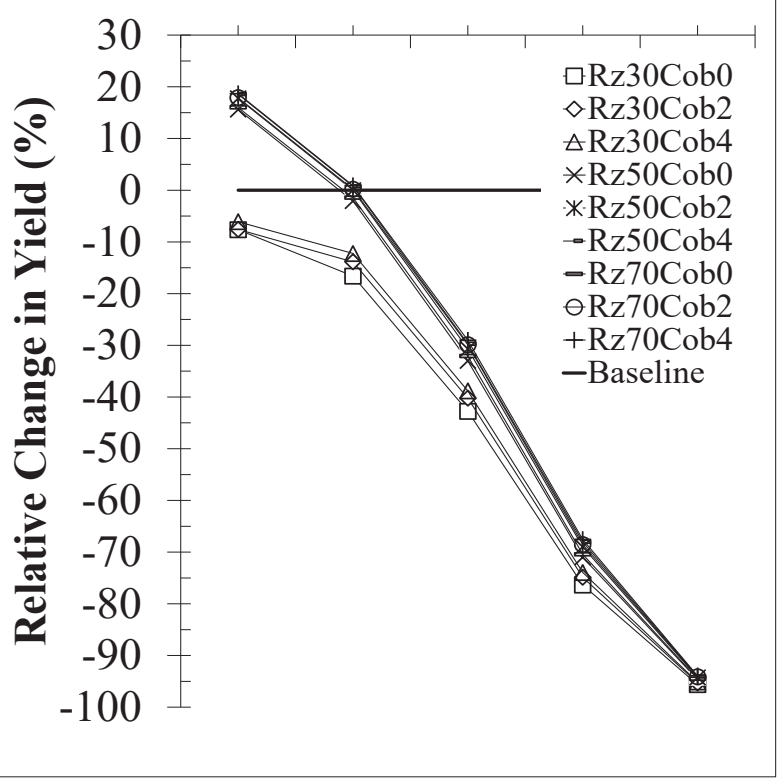

\section{(H) SETE LAGOAS}

Change in Temperature $\left({ }^{\circ} \mathrm{C}\right)$

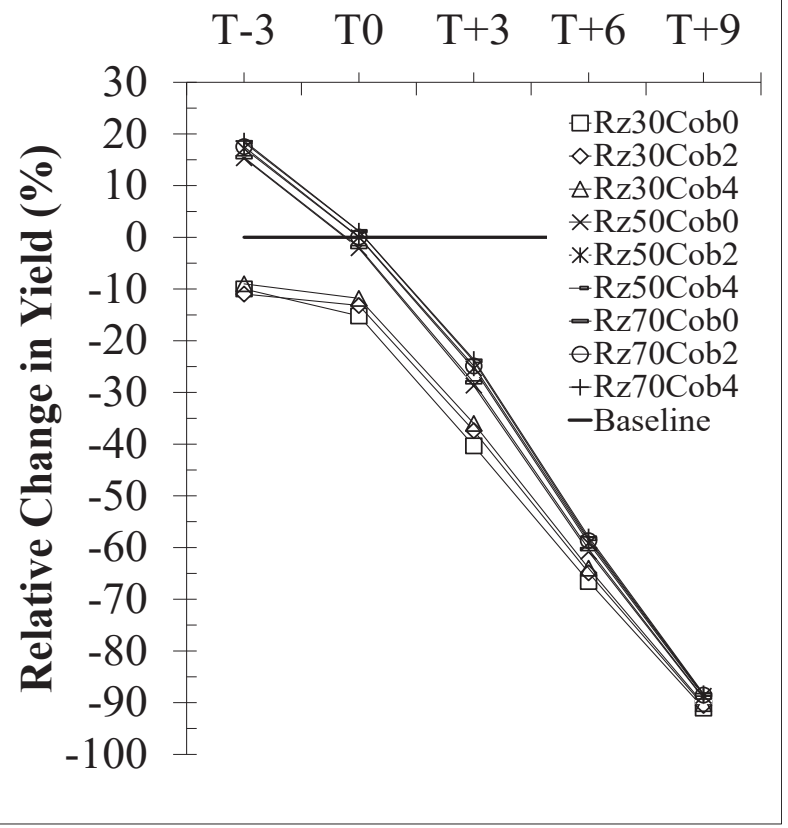

Figure 2 - Relative change in maize yield for different scenarios of temperature and of crop management strategies. Continued... 

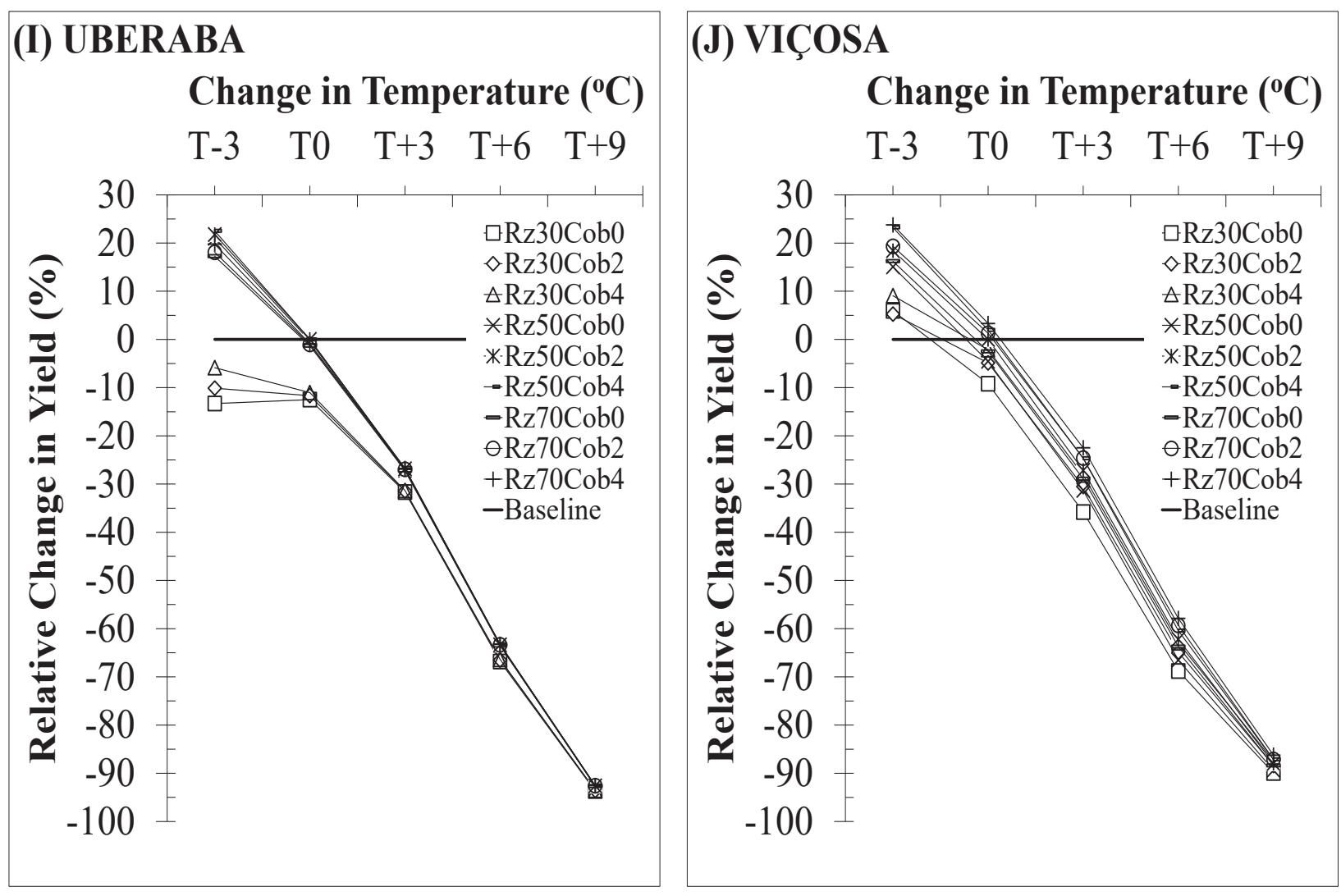

Figure 2 - Relative change in maize yield for different scenarios of temperature and of crop management strategies. Continued.

of maize, the increase in air temperature has caused lower than expected yield losses in the United States, especially under irrigated conditions (Butler and Huybers, 2013). The increase in temperature, above $23{ }^{\circ} \mathrm{C}$, causes a reduction in maize yield, which is even more accentuated when the daily values exceed $30{ }^{\circ} \mathrm{C}$ (Lobell et al., 2011). Several factors contribute to this yield reduction, among which, the increase of maintenance respiration, the reduction of soil moisture (Levis et al., 2018; Lizaso et al., 2018; Andrea et al., 2019) and the acceleration of vegetative development (Streck et al., 2012), which leads to the shortening of the maize cycle. In practice, fewer cardinal days are spent to achieve the thermal sums required in each phenological phase of maize, causing the shortening of the cycle, which by its turn, reduces the opportunity for the plant to accumulate and translocate photoassimilates to the grains (Bergamaschi and Matzenauer, 2014) and, evidently, affects yield (Cruz et al., 2011). In a modeling study conducted in Santa Maria, RS, Brazil, it was also found that the vegetative development of maize is accelerated due to the increase of temperature (Streck et al., 2012).

In all the studied regions, a practically linear reduction in the duration of the maize cycle was observed in response to temperature rise (Figure 1). For all scenarios of temperature change, the maize 
cycle duration was considerably shorter in warmer climate regions, such as in Aimorés, Araçuaí and Janaúba. In the scenario without temperature change (T0), the duration of the maize cycle in the regions of Machado, Aimorés and Paracatu was 138, 112 and 125 days, while for the scenario of $9{ }^{\circ} \mathrm{C}$ increase in the temperature, the cycle should shorten to 95,62 and 81 days, respectively. Simulations performed for the municipalities of Rio Verde and Catalão in the state of Goiás, Brazil, obtained a cycle of 126 days for a generic maize cultivar of the Aquacrop model. In warmer municipalities of the state of Mato Grosso, Brazil, the duration of the maize cycle dropped to 112 days. The study also reported that the cycle is expected to reduce from two to eight days, in a scenario of climate change in the short term, and from six to 11 days, in the medium term (Minuzzi and Lopes, 2015).

\section{Crop Management Strategies versus Change in the $\mathrm{CO}_{2}$ Concentration}

Statisticalanalysesindicated that theinteractions of root depth with $\mathrm{CO}_{2}$ concentration, crop residue on the soil surface versus $\mathrm{CO}_{2}$ concentration, and crop residue with $\mathrm{CO}_{2}$ concentration and with root depth were not significant at $5 \%$ probability. However, the individual effects on maize yield of the root depth and of the amount of residue were highly significant. The same was verified for $\mathrm{CO}_{2}$ concentration whose effect was highly significant at 5\%. A comparison of these effects on maize yield, taking as a baseline the management strategy consisted of a cultivar with 0.5 $\mathrm{m}$ of root depth and a no-till system that leaves $2 \mathrm{t}$ $\mathrm{ha}^{-1}$ of crop residue on the soil surface (Rz50Cob2), is presented in Figure 3.

In general, for all regions, regardless of the $\mathrm{CO}_{2}$ concentration and the amount of residue on the soil surface, the root depth of $0.3 \mathrm{~m}$ resulted in lower yield compared to the baseline crop (Figure 3). The deleterious effect on yield resulted from the shallow root system is even more drastic in the absence of mulching and in regions with higher temperature and less precipitation, such as Araçuaí and Janaúba (tables 2 and 4 and Figure 3). Even when 2 or $4 \mathrm{t}$ $\mathrm{ha}^{-1}$ of residue was kept on the soil surface, for a root depth of $0.3 \mathrm{~m}$, the yield drops in Janaúba and Araçuaí were greater than in the other regions. This is due to the combined effect of high temperature, with low rainfall, which causes faster depletion of the water available in the reduced volume of soil explored by the roots (Levis et al., 2018; Lizaso et al., 2018).

In regions with high temperature and less rainfall, such as Araçuaí and Janaúba, the positive response of maize crop to the increase in $\mathrm{CO}_{2}$ concentration was more pronounced, regardless of the amount of residue and the deepening of the root system to $0.5 \mathrm{~m}$ and to $0.7 \mathrm{~m}$ (Figures 3B and 3C). Higher $\mathrm{CO}_{2}$ concentration reduces the consumptive use of water due to the decrease in stomatal conductance of plants (Deryng et al., 2016). For this reason, the effect of $\mathrm{CO}_{2}$ fertilization on $\mathrm{C} 3$ and $\mathrm{C} 4$ plants is greater in environments under water stress, compared to those without water limitation (Lobell et al., 2011; Hatfield et al., 2011). Considering the baseline management scenario, the increase in $\mathrm{CO}_{2}$ concentration provided a maximum yield increase of $13 \%$ in Janaúba and 11\% in Araçuaí. The region of Viçosa presented a similar behavior of Janaúba and Araçuaí, despite of its higher annual precipitation of $1327 \mathrm{~mm}$, and a mild climate condition with maximum and minimum temperatures of $26.9^{\circ} \mathrm{C}$ and $15.8^{\circ} \mathrm{C}$, respectively. The differentiated response observed in Viçosa, in comparison to the other regions with similar temperature and precipitation conditions, 

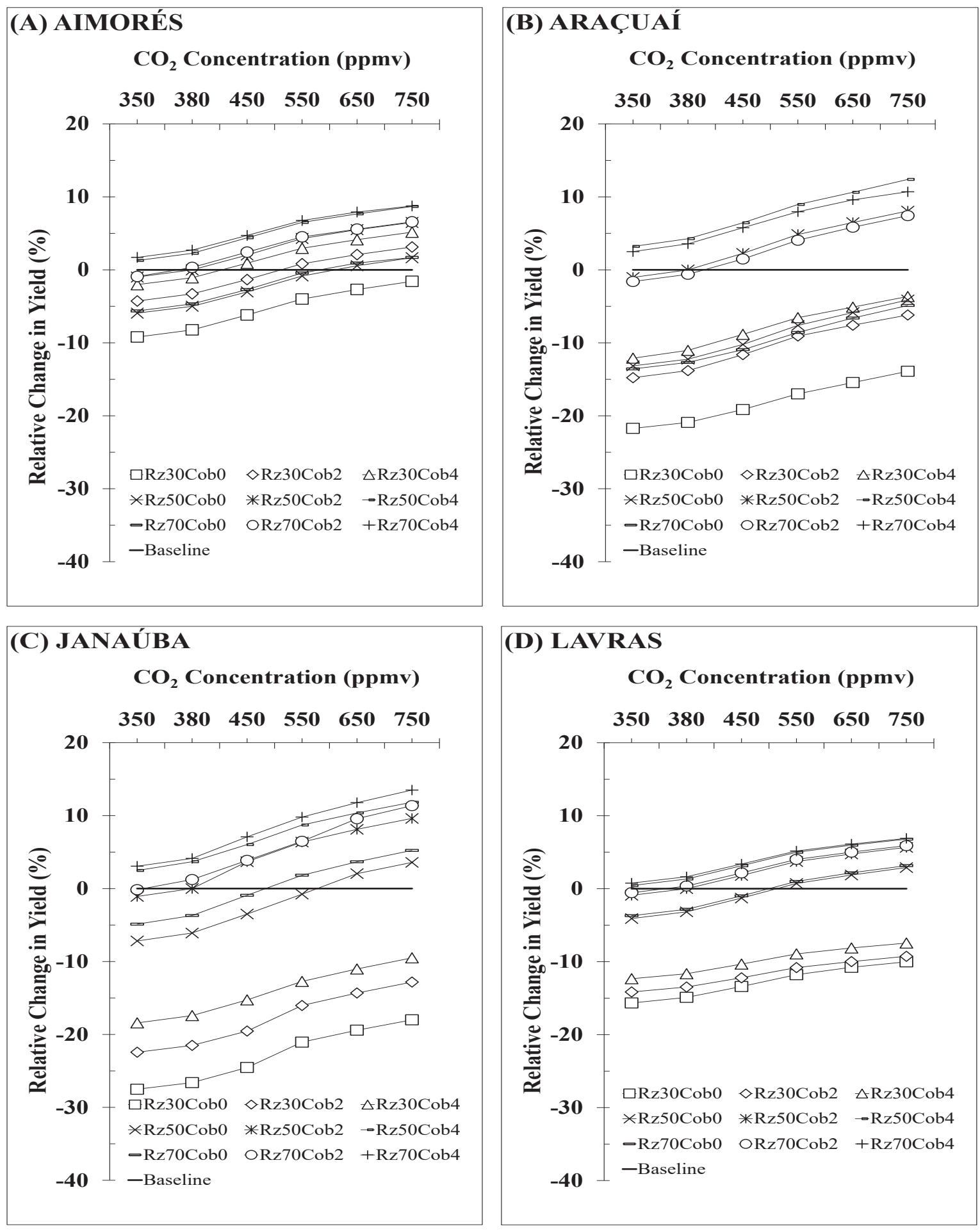

Figure 3 - Relative change in maize yield for different scenarios of $\mathrm{CO}_{2}$ concentration and of crop management strategies. 

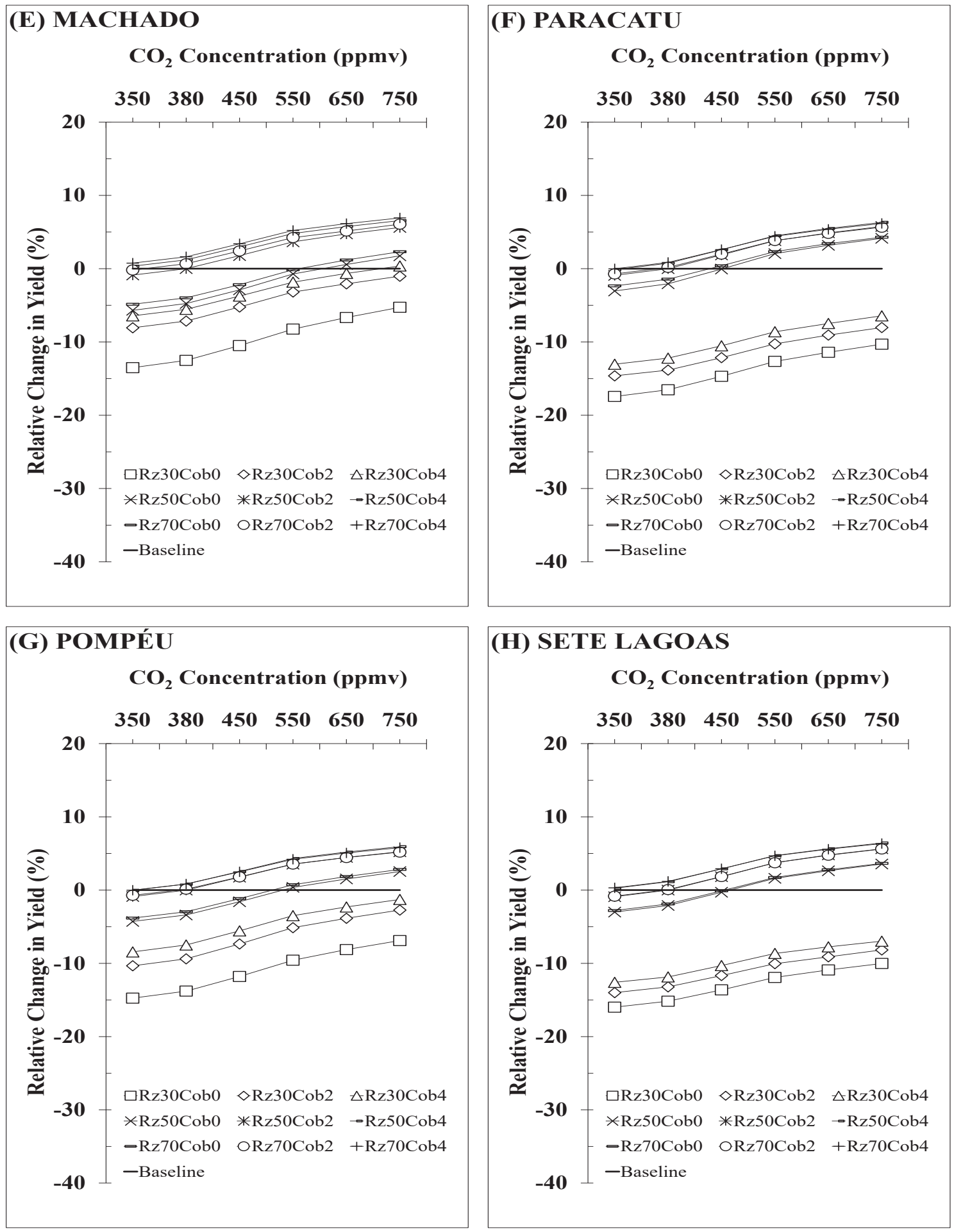

Figure 3 - Relative change in maize yield for different scenarios of $\mathrm{CO}_{2}$ concentration and of crop management strategies. Continued... 

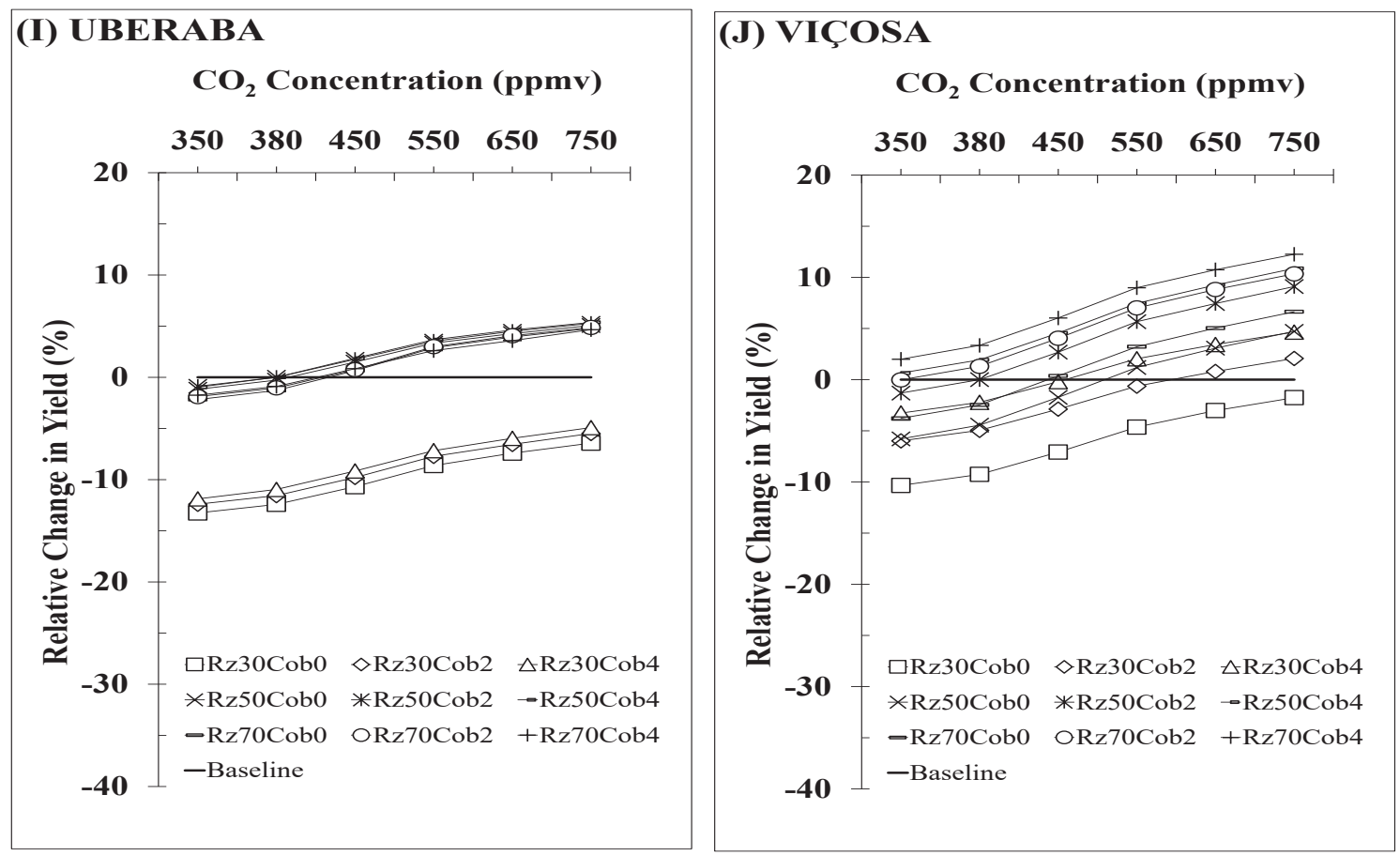

Figure 3 - Relative change in maize yield for different scenarios of $\mathrm{CO}_{2}$ concentration and of crop management strategies.

is related to the water stress to which the maize crop was subjected, due to the smaller water availability, of $46 \mathrm{~mm}$ and $66 \mathrm{~mm}$, at the $0-0.5 \mathrm{~m}$ and $0-0.70$ $\mathrm{m}$ soil layers, respectively (table 7 ). Crops grown in arid climate benefit the most from elevated $\mathrm{CO}_{2}$ concentration, especially under rainfed conditions (Deryng et al., 2016).

Possibly the response of the maize crop to enrichment with $\mathrm{CO}_{2}$ has been overestimated since the concomitant effect of changes in temperature and $\mathrm{CO}_{2}$ concentration was not accounted for in the simulations. Increased concentration of GHGs, including $\mathrm{CO}_{2}$, favors the rise of temperature, which can compromise the crop development. Therefore, the combined effect of increasing $\mathrm{CO}_{2}$ concentration and temperature is complex and still requires further studies (Hatfield et al., 2011).
Regardless of the root depth, the increase in $\mathrm{CO}_{2}$ concentration, from 350 to $750 \mathrm{ppmv}$, and the amount of crop residue on the soil surface, from 0 to $4 \mathrm{t} \mathrm{ha}^{-1}$, resulted in a continuous increase in yield (Figure 3). It is worth mentioning that, even for $\mathrm{CO}_{2}$ concentration of $750 \mathrm{ppmv}$ and of $4 \mathrm{tha}^{-1}$ of mulching, a yield plateau was not reached, suggesting a potential for increase. In all the regions, the response of maize crop to variation in the $\mathrm{CO}_{2}$ concentration was similar for the root depths of $0.5 \mathrm{~m}$ and $0.7 \mathrm{~m}$, irrespective of the amount of mulching. Therefore, for the study regions, a root depth of $0.5 \mathrm{~m}$ is still sufficient to guarantee the current levels of maize yield. Regions with milder climate and higher precipitation showed less increment in yield in response to increase in $\mathrm{CO}_{2}$ concentration, as compared to the others. Vanaja et al. (2015) found that, in spite of having a 
Table 7. Soil available water capacity for the three soil layers associated with the root system depths.

\begin{tabular}{cccc}
\hline & \multicolumn{3}{c}{ Soil Layer } \\
\cline { 2 - 4 } Region & $0-0.3 \mathrm{~m}$ & $0-0.5 \mathrm{~m}$ & $0-0.7 \mathrm{~m}$ \\
\cline { 2 - 4 } & 41 & 57 & 64 \\
\hline Aimorés & 43 & 71 & 93 \\
Araçuá́ & 34 & 56 & 80 \\
Janaúba & 37 & 62 & 87 \\
Lavras & 35 & 56 & 78 \\
Machado & 33 & 54 & 77 \\
Paracatu & 35 & 65 & 95 \\
Pompéu & 34 & 59 & 84 \\
Sete Lagoas & 43 & 69 & 96 \\
Uberaba & 28 & 46 & 66 \\
Viçosa & & & \\
\hline
\end{tabular}

C4 photosynthetic pathway, the maize crop was able to positively respond to a $\mathrm{CO}_{2}$ concentration of 550 ppmv.

\section{Conclusions}

Considering a baseline scenario, which assumes a maize crop with a root depth of $0.5 \mathrm{~m}$ and a cropping system that leaves $2 \mathrm{t} \mathrm{ha}^{-1}$ of crop residue on the soil surface, a $3{ }^{\circ} \mathrm{C}$ increase in the air temperature causes $26 \%$ to $54 \%$ yield reduction. The warmer and drier the region, the higher the yield reduction in response to the rise in temperature. The use of mulching is not capable of mitigating the air temperature increase, except in Araçuaí where a $3{ }^{\circ} \mathrm{C}$ rise can be attenuated by using $4 \mathrm{tha}^{-1}$ of crop residue on the soil surface.

For most of the study regions, deepening maize root from $0.5 \mathrm{~m}$ to $0.7 \mathrm{~m}$ is not effective to mitigate the effect of the different levels of temperature rise on maize yield. Even the combination of a root system of $0.7 \mathrm{~m}$ with $4 \mathrm{tha}^{-1}$ of crop residue on the soil surface does little to mitigate the drop in yield in response of maize to increased air temperature. In contrast, for most of the regions, any factor limiting root growth of maize to a depth of $0.30 \mathrm{~m}$, causes significant yield drop in scenarios of reducing temperature by $3^{\circ} \mathrm{C}$, no reduction or rising by $3^{\circ} \mathrm{C}$.

In general, for all study regions, regardless of the $\mathrm{CO}_{2}$ concentration and the amount of mulching, the use of a maize cultivar with a root depth of $0.3 \mathrm{~m}$ resulted in lower yield, as compared to the baseline. In warmer and drier regions, the positive response of maize to the increase in $\mathrm{CO}_{2}$ concentration was more pronounced, regardless of the amount of crop residue and of the root depth. The increased maize yield can reach $13 \%$ in the warm and dry region of Janaúba. Regardless of the root depth, the increase in $\mathrm{CO}_{2}$ concentration, from 350 to $750 \mathrm{ppmv}$, and the amount of crop residue on the soil surface, from 0 to $4 \mathrm{t} \mathrm{ha}^{-1}$, resulted in a continuous increase in yield. 


\section{Acknowledgements}

We would like to acknowledge Embrapa, Empresa Brasileira de Pesquisa Agropecuária; FAPEMIG, Fundação de Amparo à Pesquisa do Estado de Minas Gerais and CNPq, Conselho Nacional de Pesquisa e Desenvolvimento for the financial support to collect field data applied to model calibration and evaluation. I also thank CAPES, Coordenação de Aperfeiçoamento de Pessoal de Ensino Superior for providing the scholarship to Bruna Gomes Magalhães during her master's degree program.

\section{References}

ACOMPANHAMENTO DA SAFRA BRASILEIRA [DE] GRÃOS: safra 2019/20: quarto levantamento, Brasília, DF: Conab, 2020. v. 7, n. 4, 104 p.

AMARAL, T. A.; BRAGA, R. N. F. G. P.; LIMA, A. C. R.; ANDRADE, C. L. T. A modeling approach to establish strategies for maize silage production in the micro-region of Pelotas, Brazil. Revista Brasileira de Milho e Sorgo, v. 16, p. 536-555, 2017. DOI: 10.18512/1980-6477/rbms.v16n3p536-555.

ANDRADE, C. L. T.; SILVA, P. P. G.; MAGALHÃES, B. G.; PAIXÃO, J. S.; MELO, B. F.; TIGGES, C. H. P. Parametrização do modelo CSM-CERES-Maize para uma cultivar de alta produtividade. In: CONGRESSO NACIONAL DE MILHO E SORGO, 31., 2016, Bento Gonçalves. Milho e sorgo: inovações, mercados e segurança alimentar: anais. Sete Lagoas: Associação Brasileira de Milho e Sorgo, 2016.

ANDREA, M. C. S.; DALLACORT, R.; BARBIERI, J. D.; TIEPPO, R. C. Impacts of future climate predictions on second season maize in an agrosystem on a biome transition region in Mato Grosso state. Revista Brasileira de Meteorologia, v. 34, n. 2, p. 335-347, 2019. DOI: http://dx.doi.org/10.1590/010277863340241.

ASSAD, E. D.; COSTA, L. C.; MARTINS, S.; CALMON, M.; FELTRAN-BARBIERI, R.; CAMPANILI, M.; NOBRE, C. A. Papel do Plano ABC e do Planaveg na adaptação da agricultura e da pecuária às mudanças climáticas. São Paulo: WRI Brasil, 2019. Available at: <https://wribrasil. org.br/pt/publicacoes $>$. Access in: 1 April 2020.

BÄNZIGER, M.; EDMEADES, G. O.; BECK; D.; BELLON. M. Breeding for drought and nitrogen stress tolerance in maize: from theory to practice. Mexico: CIMMYT, 2000.

BERGAMASCHI, H.; MATZENAUER, R. O milho e o clima. Porto Alegre: Emater-RS: Ascar, 2014. 85 p.

BUTLER, E. E.; HUYBERS, P. Adaptation of US maize to temperature variations. Nature Climate Change, v. 3, p. 68-73, 2013. DOI: http://dx.doi. org/10.1038/NCLIMATE1585

CHAPMAN, S. C.; CHAKRABORTY, S.; DRECCER, F.; HOWDEN, S. M. Plant adaptation to climate change: opportunities and priorities in breeding. Crop \& Pasture Science, v. 63, n. 3, p. 251268, 2012. DOI: http://dx.doi.org/10.1071/CP11303

CRUZ, J. C.; CAMPANHA, M. M.; COELHO, A. M.; KARAM, D.; PEREIRA FILHO, I. A.; CRUZ, I.; GARCIA, J. C.; PIMENTEL, M. A. G.; GONTIJO 
NETO, M. M.; ALBUQUERQUE, P. E. P.; COSTA, R. V.; ALVARENGA, R. C.; QUEIROZ, V. A. V. Boas práticas agrícolas: milho. Sete Lagoas: Embrapa Milho e Sorgo, 2011. 47 p. (Embrapa Milho e Sorgo. Documentos, 119).

DEKALB. Informações sobre o híbrido DKB 390. Available at: <http://www.dekalb.com.br/produto/ detalhe?id=DKB390>. Access in: 4 May, 2016.

DERYNG, D.; ELLIOTT, J.; FOLBERTH, C.; MÜlleR, C.; PUGH, T. A. M.; BOOTE, K. J.; CONWAY, D.; RUANE, A. C.; GERTEN, D.; JONES, J. W.; KHABAROV, N.; OLIN, S.; SCHAPHO, S.; SCHMID, E.; YANG, H.; ROSENZWEIG, C. Regional disparities in the beneficial effects of rising $\mathrm{CO}_{2}$ concentrations on crop water productivity. Letters - Nature Climate Change, v. 6, p. 786-790, 2016. DOI: http://dx.doi.org/10.1038/NCLIMATE2995

FERREIRA, D. F. Sisvar: a computer statistical analysis system. Ciência e Agrotecnologia, v. 35, n. 6, p. 1039-1042, 2011. DOI: https://doi.org/10.1590/ S1413-70542011000600001

FRANCHINI, J. C.; COSTA, J. M.; DEBIASI, H.; TORRES, E. Importância da rotação de culturas para a produção agrícola sustentável no Paraná. Londrina: Embrapa Soja, 2011. 52 p. (Embrapa Soja. Documentos, 327).

GONG, F.; WU, X.; ZHANG, H.; CHEN, Y.; WANG, W. Making better maize plants for sustainable grain production in a changing climate. Frontiers in Plant Science, v. 6, article 835, 2015. DOI:https://doi. org/10.3389/fpls.2015.00835
HAMMER, G. L.; DONG, Z.; MCLEAN, G.; DOHERTY, A.; MESSINA, C.; SCHUSSLER, J.; ZINSELMEIER, C.; PASZKIEWICZ, S.; COOPER, M. Can changes in canopy and/or root system architecture explain historical maize yield trends in the U.S. corn belt? Crop Science, v. 49, n. 1, p. 299-312, 2009.DOI:https://doi.org/10.2135/ cropsci2008.03.0152

HATFIELD, J. L.; BOOTE, K. J.; KIMBALL, B. A.; ZISKA, L. H.; IZAURRALDE, R. C.; ORT, D.; THOMSON, A. M.; WOLFE, D. Climate impacts on agriculture: implications for crop production. Agronomy Journal, v. 103, n. 2, p. 351-370, 2011. DOI: https://doi.org/10.2134/agronj2010.0303

HOOGENBOOM, G.; JONES, J. W.; WILKENS, P. W.; PORTE, C. H.; BOOTE, K. J.; HUNT, L. A.; SINGH, U.; LIZASO, J. L.; WHITE, J. W.; URYASEV, O.; ROYCE, F. S.; OGOSHI, R.; GIJSMAN, A. J.; TSUJI, G. Y. Decision Support System for Agrotechnology Transfer: version 4.6. Washington: DSSAT Foundation, 2014.

HOOGENBOOM, G.; PORTER, C. H.; BOOTE, K. J.; SHELIA, V.; WILKENS, P. W.; SINGH, U.; WHITE, J. W.; ASSENG, S.; LIZASO, J. I.; MORENO, L. P.; PAVAN, W.; OGOSHI, R.; HUNT, L. A.; TSUJI, G.Y.; JONES, J. W. The DSSAT crop modeling ecosystem. In: BOOTE, J. W. (Ed.). Advances in crop modeling for a sustainable agriculture. Cambridge: Burleigh Dodds Science Publishing, 2019. p. 173-216. DOI: https://doi.org/10.19103/AS.2019.0061.10

IBGE. Levantamento Sistemático da Produção Agrícola: área plantada, área colhida e produção, por ano da safra e produto das lavouras. Available at: 
$<$ https://sidra.ibge.gov.br/tabela/1612>. Access in: 26 March 2020

\section{INTERGOVERNMENTAL PANEL ON CLIMATE} CHANGE. Climate Change: synthesis report. contribution of working Groups II, II and III to the fifth assessment report of the intergovernmental panel on climate change: 2014. Geneva, 2014. 104 p. Available at: <https://www.ipcc.ch/report/ar5/syr/>. Access in: 20 April 2016.

JING, Q.; SHANG, J.; HUFFMAN, T.; QIAN, B.; PATTEY, E.; LIU, J.; DONG, T.; DRURY, C. F.; TREMBLAY, N. Using the CSM-CERES-Maize model to assess the gap between actual and potential yields of grain maize. Journal of Agricultural Science, v. 155, p. 155-239, 2016. DOI:10.1017/ S0021859616000290.

KINIRY, J. R.; ROSENTHAL, W. D.; JACKSON, B. S.; HOOGENBOOM, G. Predicting leaf development of crop plants. In: HODGES T. (Ed.). Predicting crop phenology. Boca Raton: CRC Press, 1991. p. 29-42.

LABEGALINI, N. S.; BUCHELT, A. C.; ANDRADE, L.; OLIVEIRA, S. C.; CAMPOS, L. M. Desenvolvimento da cultura do milho sob efeitos de diferentes profundidades de compactação de solo. Revista de Agricultura Neotropical, v. 3, n. 4, p. 7-11, 2016. DOI: https://doi.org/10.32404/rean. v3i4.1102

LEVIS, S.; BADGER, A.; DREWNIAK, B.; NEVISON, C.; REN, X. CLMcrop yields and water requirements: avoided impacts by choosing RCP 4.5 over 8.5. Climatic Change, v. 146, p. 501-505, 2018. DOI:https://doi.org/10.1007/s10584-016-1654-9
LIN, Y.; FENG, Z.; WU, W.; YANG, Y.; ZHOU, Y.; XU, C. Potential impacts of climate change and adaptation on maize in Northeast China. Agronomy Journal, v. 109, n. 4, p. 1476-1490, 2017. DOI:10.2134/agronj2016.05.0275.

LIZASO, J. I.; RUIZ-RAMOS, M.; RODRÍGUEZ, L.; GABALDON-LEAL, C.; OLIVEIRA, J. A.; LORITE, I. J.; SÁNCHEZ, D.; GARCÍA, E.; RODRÍGUEZ, A. Impact of high temperatures in maize: phenology and yield components. Field Crops Research, v. 216, p. 129-140, 2018. DOI: https://doi. org/10.1016/j.fcr.2017.11.013

LOBELL, D. B.; BÄNZIGER, M.; MAGOROKOSHO, C.; VIVEK, B. Nonlinear heat effects on African maize as evidenced by historical yield trials. Nature Climate Change, v. 1, n. 1, p. 4245, 2011. DOI: https://doi.org/10.1038/nclimate1043

MAGAlHÃES, B. G.; ANDRADE, C. L. T.; LOPES, D. C.; STEIDLE NETO, A. J.; AMARAL, T. A. Mitigating the effects of future climate on maize productivity. Agrometeoros, v. 27, n. 2, p. 259270, 2019. DOI: http://dx.doi.org/10.31062/agrom. v27i2.26515

MALDANER, L. J.; HORING, K.; SCHNEIDER, J. F.; FRIGO, J. P.; AZEVEDO, K. D.; GRZESIUCK, A. E. Exigência agroclimática da cultura do milho (Zea mays). Revista Brasileira de Energias Renováveis, v. 3, n. 1, p. 13-23, 2014.

MEISTER, R.; RAJANI, M. S.; RUZICKA, D.; SCHACHTMAN, D. P. Challenges of modifying root traits in crops for agriculture. Trends in Plant Science., v. 19, n. 12, p. 779-788, 2014. DOI: http:// 
dx.doi.org/10.1016/j.tplants.2014.08.005

MINUZZI, R. B.; LOPES, F. Z. Desempenho agronômico do milho em diferentes cenários climáticos no Centro-Oeste do Brasil. Revista Brasileira de Engenharia Agrícola e Ambiental, v. 19, n. 8, p. 734-740, 2015. DOI: https://doi. org/10.1590/1807-1929/agriambi.v19n8p734-740

MORAES, M. T.; DEBIASI, H.; FRANCHIN, J. C.; SILVA, V. R. Benefícios das plantas de cobertura sobre as propriedades físicas do solo. In: TIECHER, T. (Org.). Manejo e conservação do solo e da água em pequenas propriedades rurais no Sul do Brasil: práticas alternativas de manejo visando a conservação do solo e da água. Porto Alegre: UFRGS, 2016. p. 23-34.

NASA. Earth Observatory. Global warming. 2010. Available at: <https://earthobservatory.nasa.gov/ features/GlobalWarming/page2.php $>$. Access in: 14 Jan. 2020.

PICKERING, N. B.; HANSEN, J. W.; JONES, H.; GODWIN, D. Weatherman: a utility for managing and generating daily weather data. Agronomy Journal, v. 86, n. 2, p. 332-337, 1994.

DOI:https://doi.org/10.2134/agronj1994.000219620 $08600020023 x$

RANAIVOSON, L; NAUDIN, K.; RIPOCHE, A. CORBEELS. M. Agro-ecological functions of crop residues under conservation agriculture. A review. Agronomy for Sustainable Development, v. 37, article 26, 2017. DOI: http://dx.doi.org/10.1007/ s13593-017-0432-z
RODRIGUES, E. J.; CARAMORI, P. H.; MORAIS, H.; BIANCO, R. Profundidade de raízes de milho safrinha em sucessão com soja em três sistemas de cultivos no Norte do Paraná. In: SEMINÁRIO NACIONAL [DE] MILHO SAFRINHA, 14., 2017, Cuiabá. Construindo sistemas de produção sustentáveis e rentáveis: anais. Sete Lagoas: Associação Brasileira de Milho e Sorgo, 2017.

ROSENZWEIG, C.; JONES, J. W.; HATFIELD, J. L.; RUANE, A. C.; BOOTE, K. J.; THORBURN, P.; ANTLE, J. M.; NELSON, G. C.; PORTER, C.; JANSSEN, S.; ASSENG, S.; BASSO, B.; EWERT, F.; WALLACH, D.; BAIGORRIA, G.; WINTER, J. M. The agricultural model intercomparison and improvement project (AgMIP): protocols and pilot studies. Agricultural and Forest Meteorology, v. 170, p.166-182, 2013. DOI: https://doi. org/10.1016/j. agrformet.2012.09.011

ROSENZWEIG， C.; ELLIOTT, J.; DERYNG, D.; RUANE, A. C.; MÜLLER, C.; ARNETH, A.; BOOTE, K. J.; FOLBERTH, C.; GLOTTER, M.; KHABAROV, N.; NEUMANN, K; PIONTEK, F.; PUGH, T. A. M.; SCHMID, E.; STEHFEST, E.; YANG, H.; JONES, J. W. Assessing agricultural risks of climate change in the 21 st century in a global gridded crop model intercomparison. Proceedings of the National Academy of Sciences, v. 111, n. 9, p. 3268-3273, 2014. DOI: https://doi.org/10.1073/ pnas. 1222463110

SALMERÓN, M.; CAVERO, J.; ISLA, R.; PORTER, C. H.; JONES, J. W.; BOOTE, K. .J. DSSAT nitrogen cycle simulation of cover crop-maize rotations under irrigated mediterranean conditions. Agronomy Journal, v. 106, n. 4, p. 1283-1296, 2014. DOI: 
https://doi.org/10.2134/agronj13.0560

SANS, L. M. A.; SANTANA, D. P. Cultivo do milho: clima e solo. Sete Lagoas: Embrapa Milho e Sorgo, 2002. 4 p. (Embrapa Milho e Sorgo. Comunicado Técnico, 38).

SCOPEL, E.; SILVA, F. A. M.; CORBEELS, M.; AFFHOLDER, F.; MARAUX, F. Modelling crop residue mulching effects on water use and production of maize under semi-arid and humid tropical conditions. Agronomie, v. 24, n. 6/7, p. 383-395, 2004. DOI: https://doi.org/ 10.1051/agro:2004029

SOLER, C. M. T.; SENTELHAS, P. C.; HOOGENBOOM, G. Application of the CSMCERES - Maize model for planting date evaluation and yield forecasting for maize grown off-season in a subtropical environment. European Journal of Agronomy, v. 27, n. 2/4, p. 165-177, 2007. DOI: https://doi.org/10.1016/j.eja.2007.03.002
SOUZA, T. T.; ANTOLIN, L. A. S.; BIANCHINI, V. J. M.; PEREIRA, R. A. A.; SILVA, E. H. F. M.; MARIN, F. R. Longer crop cycle lengths could offset the negative effects of climate change on Brazilian maize. Bragantia, v. 78, n. 4, p. 622-631, 2019. DOI: http://dx.doi.org/10.1590/1678-4499.20190085

STRECK, N. A.; SILVA, S. D. D.; LANGNER, J. A. Assessing the response of maize phenology under elevated temperature scenarios. Revista Brasileira de Meteorologia, v. 27, n. 1, p. 1-12, 2012. DOI: https://doi.org/10.1590/S0102-77862012000100001

TAIZ, L.; ZEIGER, E. Fisiologia vegetal. 4. ed. Porto Alegre: Artmed, 2009.

VANAJA, M.; MAHESWARI, M.; LAKSHMI, N. J.; SATHISH, P.; YADAV, S. K.; SALINI K.; VAGHEERA, P.; KUMAR, G. V.; RAZAK, A. Variability in growth and yield response of maize genotypes at elevated $\mathrm{CO} 2$ concentration. Advances in Plants and Agricultural Research, v. 2, n. 2, p. 63-66, 2015. DOI: http://dx.doi.org/10.15406/ apar.2015.02.00042 